\title{
Effect of vehicular traffic, remote sources and new particle formation on the activation properties of cloud condensation nuclei in the megacity of São Paulo, Brazil
}

\author{
Carlos Eduardo Souto-Oliveira ${ }^{1,2}$, Maria de Fátima Andrade ${ }^{3}$, Prashant Kumar ${ }^{4,5}$, Fábio Juliano da Silva Lopes ${ }^{3,6}$, \\ Marly Babinski ${ }^{1}$, and Eduardo Landulfo ${ }^{6}$ \\ ${ }^{1}$ Geochronological Research Centre, Institute of Geosciences, University of São Paulo, São Paulo, 05508-080, Brazil \\ ${ }^{2}$ Chemistry Research Centre, UNIFIEO, São Paulo, 06018-903, Brazil \\ ${ }^{3}$ Department of Atmospheric Sciences, Institute of Astronomy, Geophysics and Atmospheric Sciences, \\ University of São Paulo, São Paulo, 05508-090, Brazil \\ ${ }^{4}$ Department of Civil and Environmental Engineering, Faculty of Engineering and Physical Sciences (FEPS), \\ University of Surrey, Guilford GU2 7XH, UK \\ ${ }^{5}$ Environmental Flow (EnFlo) Research Centre, Faculty of Engineering and Physical Sciences (FEPS), \\ University of Surrey, Guildford GU2 7XH, UK \\ ${ }^{6}$ Nuclear and Energy Research Institute, IPEN-CNEN, Centre for Laser and Applications (CLA), \\ São Paulo, 05508-970, Brazil
}

Correspondence to: Carlos Eduardo Souto-Oliveira (carlos.edu.oliveira@usp.br)

Received: 18 March 2016 - Published in Atmos. Chem. Phys. Discuss.: 21 April 2016

Revised: 2 November 2016 - Accepted: 2 November 2016 - Published: 24 November 2016

\begin{abstract}
Atmospheric aerosol is the primary source of cloud condensation nuclei (CCN). The microphysics and chemical composition of aerosols can affect cloud development and the precipitation process. Among studies conducted in Latin America, only a handful have reported the impact of urban aerosol on CCN activation parameters such as activation ratio (AR) and activation diameter $\left(D_{\text {act }}\right)$. With over 20 million inhabitants, the Metropolitan Area of São Paulo (MASP) is the largest megacity in South America. To our knowledge, this is the first study to assess the impact that remote sources and new particle formation (NPF) events have on CCN activation properties in a South American megacity. The measurements were conducted in the MASP between August and September 2014. We measured the $\mathrm{CCN}$ within the $0.2-1.0 \%$ range of supersaturation, together with particle number concentration (PNC) and particle number distribution (PND), as well as trace-element concentrations and black carbon (BC). NPF events were identified on $35 \%$ of the sampling days. Combining multivariate analysis in the form of positive matrix factorization (PMF) with an aerosol profile from lidar and HYSPLIT model anal-
\end{abstract}

yses allowed us to identify the main contribution of vehicular traffic on all days and sea salt and biomass burning from remote regions on 28 and $21 \%$ of the sampling days, respectively. The AR and $D_{\text {act }}$ parameters showed distinct patterns for daytime with intense vehicular traffic and nighttime periods. For example, $\mathrm{CCN}$ activation was lower during the daytime than during the nighttime periods, a pattern that was found to be associated mainly with local road-traffic emissions. A decrease in CCN activation was observed on the NPF event days, mainly due to high concentrations of particles with smaller diameters. We also found that aerosols from sea salt, industrial emissions, and biomass burning had minor effects on $D_{\text {act }}$. For example, nights with biomass burning and vehicular emissions showed slightly lower CCN activation properties than sea-salt, industrial and non-event nights. Our results show that particulate matter from local vehicular emissions during the daytime has a greater effect on $\mathrm{CCN}$ activation parameters than that from remote sources. 


\section{Introduction}

Atmospheric aerosol has been the focus of numerous studies, because of its adverse effects on public health and climate (Heal et al., 2012). Aerosol particles are a significant source of cloud condensation nuclei (CCN). Owing to their microphysics and chemical composition, aerosol particles can affect cloud development and the precipitation process. The high concentrations of $\mathrm{CCN}$ in the air favor the formation of clouds with small droplets, which can lead to suppression of precipitation in shallow and short-lived clouds (Andreae and Rosenfeld, 2008). Such phenomena have been observed at different places. A study carried out in the Brazilian Amazon showed a reduction in precipitation during biomass-burning events, due to greater scavenging from smoky clouds than from clouds formed under clean (blue and green ocean) air masses. The smoky clouds were shown to form at higher altitudes ( $>4 \mathrm{~km})$, due to their smaller droplet size, and to produce hydrometeors including isolated intense showers and thunderstorms (Andreae et al., 2004; Freud et al., 2008).

The CCN activation properties can be estimated by parameters such as activation ratio (AR) and activation diameter $\left(D_{\text {act }}\right)$. In several studies representing different locations of the world, these parameters have been employed for determining the efficiency of aerosol particles in acting as $\mathrm{CCN}$. The variability of these parameters is dependent on size and chemical composition of particles. In general, $D_{\text {act }}$ is more sensitive to the chemical composition of aerosols, whereas the AR is related to particle size and chemical composition. Large particles, inorganic salts and polar organic molecules are typically more hygroscopic than smaller particles and non-polar molecules (e.g., hydrocarbons). Some studies have reported that aerosol from air masses containing pollutants (e.g., urban, fresh traffic and biomass-burning emissions) are less efficient in activating $\mathrm{CCN}\left(>D_{\text {act }}\right.$ and $\left.<\mathrm{AR}\right)$ than nonpolluted (e.g., forest and marine) air masses (Frank et al., 2006; Andreae and Rosenfeld, 2008; Quinn et al., 2008; Furutani et al., 2008; Burkart et al., 2011; Deng et al., 2013; Leng et al., 2013; Paramonov et al., 2013). However, studies carried out at different locations and under different environmental conditions have demonstrated that aged polluted aerosols present $\mathrm{CCN}$ activation properties similar to those of non-polluted or even marine environment air (Peng et al., 2014). Those observations are supported by the growth of particles, atmospheric processing of non-soluble organics and mixture with more hygroscopic compounds such as sulphate, nitrate and organic acids (Andreae et al., 2004; McFiggans et al., 2006; Quinn et al., 2008; Furutani et al., 2008; Dusek et al., 2010; Bougiatioti et al., 2011; Zhang et al., 2014).

Aerosols originate from primary and secondary processes. Primary aerosols are emitted into the atmosphere directly by anthropogenic and natural sources. In contrast, secondary aerosols are formed in the atmosphere through the nucleation of no- or low-volatile gases containing inorganic and organic compounds, followed by growth to larger particles (Holmes, 2007). New particle formation (NPF) directly affects particle number concentration (PNC), particle size distribution (PND) and the optical properties of aerosols, as well as the properties of CCN and clouds. These events have been recently studied in urban, coastal and forest environments (Kulmala et al., 2004; Dal Maso et al., 2005; Backman et al., 2012; Betha et al., 2013; Peng et al., 2014; Nie et al., 2014; An et al., 2015; Sorribas et al., 2015; Kumar et al., 2014). However, there have been only a few studies evaluating the effect of NPF on CCN properties (Dusek et al., 2010; Yue et al., 2011; Sihto et al., 2011; Paramonov et al., 2013).

Typically, nucleation events occur in clean air under high solar radiation conditions. Many authors have shown that sulphuric acid and precursor species $\left(\mathrm{SO}_{2}\right.$, hydroxyl, $\mathrm{NH}_{3}$ and oxidized organic compounds) play important roles in the nucleation process (Yue et al., 2011; Andreae, 2013; Long et al., 2016). Reche et al. (2011) suggested that the occurrence of $\mathrm{SO}_{2}$ peaks contributes to midday nucleation bursts as a function of the sources. Kumar et al. (2014) discussed the different conditions for the secondary formation of particles over different types of urban areas. Recent studies have demonstrated the importance of oxidized organic vapors to driving NPF nucleation with $\mathrm{H}_{2} \mathrm{SO}_{4}$ and enhancing secondary particle growth (Metzger et al., 2010; Donahue et al., 2013). Zhu et al. (2014) demonstrated the importance of secondary organic aerosols (SOAs) to particle growth over urban sites with different levels of pollution.

Volatile organic compounds (VOCs) constitute a fundamental precursor of SOAs and tropospheric ozone $\left(\mathrm{O}_{3}\right)$. Primary organic aerosols originate from biogenic sources (isoprene, terpenes, dimethyl sulphide and dicarboxylic acids) and anthropogenic sources (biomass burning and traffic), thereafter being emitted directly into the atmosphere. Atmospheric species such as hydroxyl radicals and $\mathrm{O}_{3}$ play a major role in VOC chemical degradation and the consequent formation of SOAs, which contain polar oxygenated functional groups (Hallquist et al., 2009). Recent studies have confirmed that the SOA yield is dependent on high concentrations of nitrogen oxides $\left(\mathrm{NO}_{x}\right)$, which explain the formation of certain SOAs, such as those derived from isoprene degradation (Shilling et al., 2013; Yuan et al., 2013). Another study, carried out in California, showed that vehicular emissions play an important role in the formation of urban SOAs (Ortega et al., 2016). In MASP, biofuels (ethanol and biodiesel) increase the emission of carbonyl compounds, which can be precursors of secondary oxygenated pollutants. In one study conducted in the MASP, Oyama et al. (2015) showed the emission factors for light-duty vehicles, which run on gasohol or ethanol, and for heavy-duty vehicles, which run on biodiesel. The authors found that oxygenated hydrocarbon compounds accounted for a major proportion of the aerosol composition. Those same authors also reported that, during biodiesel combustion, heavy-duty vehicles in the MASP emit greater quantities of volatile nitrogen com- 
pounds, which are associated with the $\mathrm{NO}_{x}$ chemistry, than light-duty vehicles in the MASP. Wallington et al. (2016) showed that engine calibration is a determinant of $\mathrm{NO}_{x}$ emissions, which are higher from biodiesel-burning vehicles. The use of biofuels has introduced new challenges for the description of atmospheric chemistry, by increasing the emissions of carbonyl and polycyclic aromatic hydrocarbons (PAHs, including those containing nitrogen and those that are oxygenated), as shown by Karavalakis et al. (2011).

With over 20 million inhabitants, the MASP is the biggest megacity in South America. Therefore, the MASP represents an important city for global-scale atmospheric studies. The MASP fleet comprises more than 7 million vehicles, which constitute one of the main sources of particles, together with a variety of industries and construction activities (IBGE, 2010). To date, there has been only one study measuring and modeling CCN in the MASP (Almeida et al., 2014). In general, there has been a limited number of studies reporting CCN, PNC and PND measurements, comparing Latin American cities with those in Europe and United States in terms of the effects that those properties have on the atmosphere (IPCC, 2015).

The aim of this study was to evaluate $\mathrm{CCN}$ activation properties under the influence of local and remote sources, as well as to identify NPF events. We measured CCN simultaneously with PNC, PND, black carbon (BC) and trace elements. PND contour plots were constructed in order to identify and classify NPF events. Light detection and ranging (lidar) analyses and hybrid single particle lagrangian integrated trajectory (HYSPLIT) analyses (Draxler and Rolph, 2015) were combined with multivariate analysis in the form of positive matrix factorization (PMF) in order to identify air masses from remote sources in the MASP. We evaluated the effects that those air masses associate with local sources and NPF events had on CCN activation properties. To our knowledge, this is the first study evaluating the effects of remote sources and NPF events on CCN activation properties in a megacity in South America.

\section{Methodology}

\subsection{Site description and meteorological data}

The MASP $\left(23.5^{\circ} \mathrm{S} ; 46.6^{\circ} \mathrm{W}\right)$ is an urban region encompassing an area of $7946 \mathrm{~km}^{2}$, in the southwestern region of Brazil (Fig. 1). With over 20 million inhabitants, the MASP is the largest megacity in South America and ranks among the ten most populous in the world. The MASP is situated in a sedimentary basin within the state of São Paulo (the Tietê River valley, which has a mean elevation of $720 \mathrm{~m}$ ), approximately $45 \mathrm{~km}$ northwest of the Atlantic Ocean.

The measurements were taken on the rooftop of the Instituto de Astronomia, Geofísica e Ciências Atmosféricas (IAG, Institute of Astronomy, Geophysics and Atmospheric

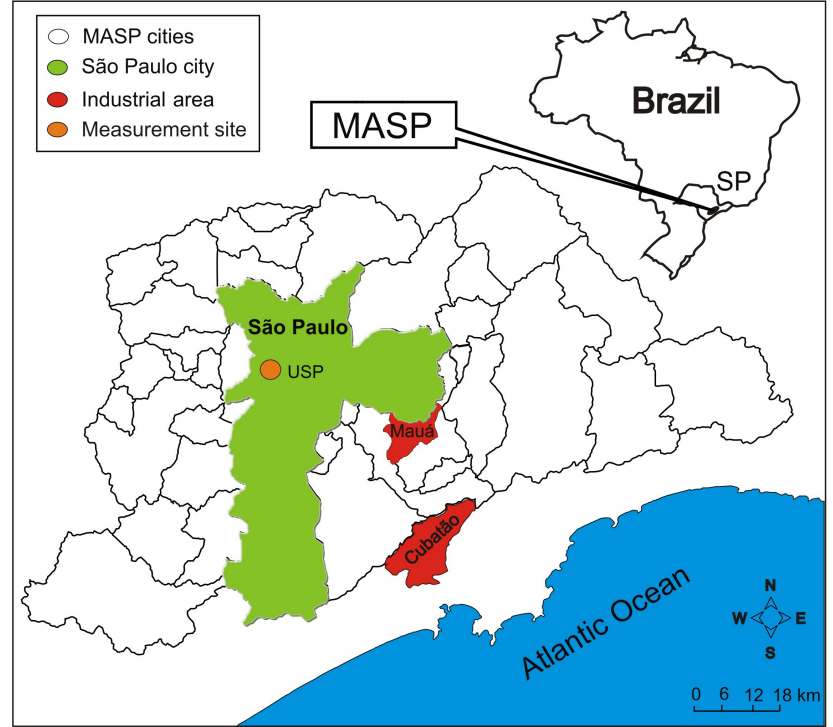

Figure 1. Map of Metropolitan Area of São Paulo (MASP). The city of São Paulo proper appears in green. Measurement and sampling sites are located on the campus of the University of São Paulo, represented by an orange circle. The cities of Cubatão and Mauá, both of which comprise large industrial areas appear in red.

Sciences) on the main campus of the University of São Paulo (USP, $23.56^{\circ} \mathrm{S} ; 46.73^{\circ} \mathrm{W}$ ), which is situated in the western region of the city. There are two main roads (the Marginal Pinheiros and the Marginal Tietê), approximately $1 \mathrm{~km}$ northeast and $4 \mathrm{~km}$ north of the sampling site, respectively. During the daytime period (07:00-19:00 local time), those roads have a high mean hourly traffic density (8000 automobiles, 1500 motorcycles, 220 trucks and 90 buses). At night, traffic volume is less than half of what is noted during the day and is dominated by heavy-duty vehicles (mainly trucks), which are not allowed to circulate during the daytime hours. Other important sources of particles in the MASP are construction sites on and near the USP campus and a cement industry about $2 \mathrm{~km}$ to the west. The major industrial areas (Mauá and Cubatão) are respectively located approximately 30 and $45 \mathrm{~km}$ to the southeast, the industrial city of Cubatão being located in the coastal region (Fig. 1).

\subsection{Measurements of $\mathrm{CCN}$}

The CCN were counted in a single-column continuous-flow stream-wise thermal gradient chamber (CCN-100; Droplet Measurement Technologies, Boulder, CO, USA). The supersaturated water vapor is generated inside the column center line (radius, $0.9 \mathrm{~mm}$; length, $360 \mathrm{~mm}$; and wall thickness, $8 \mathrm{~mm}$ ), which is controlled by the gradient temperature. When the supersaturation (SS) generated is greater than the critical SS, the particle grows to the critical $D_{\text {act }}$, after which it has the potential to become a cloud droplet. As the activated particles leave the column chamber, those in the 0.75 
$10 \mu \mathrm{m}$ size range are counted by an optical particle counter (OPC), which employs a standard light scattering technique (Roberts and Nenes, 2005).

All samples were collected between 19 August and 3 September 2014. The CCN counter was operated at a flow rate of $0.5 \mathrm{~L} \mathrm{~min}^{-1}$ with variable supersaturation $(0.2,0.4$, $0.6,0.8$ and $1.0 \%)$. Each cycle $(\sim 25 \mathrm{~min})$ corresponds to measurements of all supersaturation, each supersaturation being measured for $5 \mathrm{~min}$; our analysis considered only the data for steady-states upper saturation.

\subsection{Measurements of size-resolved particles}

The PND and PNC were measured with a scanning mobility particle sizer (SMPS, model 3936; TSI Inc., St. Paul, MN, USA). The SMPS consists of a differential mobility analyzer (DMA, model 3080; TSI Inc.) and a condensation particle counter (CPC, model 3010; TSI Inc.). The DMA separates particles according to their electrical mobility, and the particles that pass through the DMA column are counted by the CPC (Kumar et al., 2010). In the CPC, particles grow into droplets by condensation of alcohol vapor and are then counted by a laser beam.

The aerosol size distribution was measured in the 10$450 \mathrm{~nm}$ range, particles being scanned in 22 diameter size bins, with a $5 \mathrm{~min}$ time resolution. The gas sample and sheath flow rate were 1.0 and $6.0 \mathrm{~L} \mathrm{~min}^{-1}$, respectively. Determining PNCs from the SMPS has been found to result in the undercounting of particles during ambient measurements, mainly due to lower DMA transfer probability or deviation in sampling and sheath flow rates (Almeida et al., 2014). Another deviation is related to the different diameter size range of particles measured by the SMPS $(10-450 \mathrm{~nm})$ and CCN $(<10 \mu \mathrm{m})$, which can lead to overestimation of AR values, as calculated from the CCN / PNC ratio. A correction factor of 1.3 was applied to the entire data set in order to correct for undercounting during the measurement of PNCs and for overestimation of the AR. That factor was obtained by linear fitting of scatterplot data (CCN vs. $\mathrm{PNC})$ with $\mathrm{AR}$ values $>1$.

\subsection{Measurements of $\mathrm{BC}$ and trace-element species and positive matrix factorization analysis}

A micro-orifice uniform deposit impactor (MOUDI) was used in order to collect particles measuring $<0.056,0.05618$, $0.1,0.18,0.32,0.56,1.0,1.8,3.2,5.6$ and $10 \mu, \mathrm{m}$. The MOUDI selects particles by the size of its orifices and operates with a sampling air flow of $30 \mathrm{~L} \mathrm{~min}^{-1}$. In each stage, the particles larger than the size of micro-orifice were collected on polycarbonate filters (Whatman, $47 \mathrm{~mm}$ diameter, $8 \mu$, m pore size). The sampling intervals were $12 \mathrm{~h}(07: 00-$ 19:00 and 19:00-07:00 LT). After the sampling, the filters were stored in a temperature- and humidity-controlled room for subsequent analysis.
The aerosol mass concentrations were determined gravimetrically before and after the sampling; the filters were weighed on a microbalance with a $1 \mu \mathrm{g}$ readability (MettlerToledo, Columbus, OH, USA). Elemental concentrations were determined by a energy dispersive $\mathrm{x}$-ray fluorescence spectrometer (EDX 700; Shimadzu Corporation, Analytical Instruments Division, Tokyo, Japan). The spectrometer operates at $5-50 \mathrm{kV}$ and $1-1000 \mu \mathrm{A}$, using a low-power Rh-target tube, and the elemental characteristic X-ray radiation emitted from the aerosol sample is detected with an $\mathrm{Si}(\mathrm{Li})$ detector. The spectra obtained were processed and quantified with the Win-QXAS program, available from the International Atomic Energy Agency (http://www.iaea.org/OurWork/ST/ NA/NAAL/pci/ins/xrf/pciXRFdown.php). We measured BC by optical reflectance with a smoke stain reflectometer (model 43D; Diffusion Systems Ltd, London, UK). Visible light was emitted from a tungsten lamp, and the reflected radiation was detected. The empirical calibration curve that converts the reflected signal to BC concentrations was obtained. The light absorption by the carbonaceous fraction present in atmospheric aerosol is correlated with elemental carbon.

Source apportionment analyses were performed using the PMF model (version 5.0), an operational system from the United States Environmental Protection Agency. The analysis was performed for total concentrations of trace elements and $\mathrm{BC}$ and for average $\mathrm{CO}$ concentrations. The number of factors $(n=4)$ was adjusted to obtain the best $Q_{\text {theory }} \approx$ $Q_{\text {robust }}$ and physical validity of the model. Estimation of the goodness of the model fit was achieved by minimal values of $Q$ and a scaled residual between -2 and +2 , following the recommendations of Reff et al. (2007).

\subsection{Monitoring of gases and ultraviolet radiation}

To determine the importance of the concentrations of certain gases $\left(\mathrm{SO}_{2}, \mathrm{O}_{3}, \mathrm{NO}, \mathrm{CO}\right.$ and $\left.\mathrm{NO}_{x}\right)$ and ultraviolet (UV) radiation on NPF event days, we considered the hourly values of the compounds measured at air quality stations operated by the São Paulo State Companhia de Tecnologia de Saneamento Ambiental (CETESB, Environmental Protection Agency). The $\mathrm{O}_{3}$ and UV radiation were measured at a CETESB station on the USP campus, approximately $500 \mathrm{~m}$ from the IAG. The $\mathrm{SO}_{2}, \mathrm{O}_{3}, \mathrm{NO}$ and $\mathrm{NO}_{x}$ data were obtained from four CETESB stations located off of the USP campus: $7 \mathrm{~km}$ to the northwest (Osasco), $5 \mathrm{~km}$ to the north (Marginal Pinheiros), $10 \mathrm{~km}$ to the southeast (Congonhas) and $5 \mathrm{~km}$ to the southwest (Taboão da Serra). Those four stations were chosen in order to represent the influence of wind direction on the behavior of the particulate matter concentrations.

\subsection{Lidar and trajectory analyses}

A Raman lidar system installed at the Brazilian Nuclear and Energy Research Institute, designated Lidar do Município de 
São Paulo I (MSP-Lidar I, lidar I of the Municipality of São Paulo), approximately $400 \mathrm{~m}$ from the IAG site, was employed in order to take independent measurements related to particle extinction profiles and backscatter coefficients, thus determining the particle extinction-to-backscatter ratio, at 532 and $355 \mathrm{~nm}$, respectively. The MSP-Lidar I system belongs to the Latin American Lidar Network (http://lalinet. org), a federative coordinated lidar network focused on the vertically resolved monitoring of the particle optical properties distribution over Latin America (Guerrero-Rascado et al., 2014, 2016). The MSP-Lidar I system comprises a commercial Nd:YAG laser operating at 355 and $532 \mathrm{~nm}$. The output energy per pulse is $400 \mathrm{~mJ}$ for $532 \mathrm{~nm}$ and $230 \mathrm{~mJ}$ for $355 \mathrm{~nm}$, at a repetition rate of $10 \mathrm{~Hz}$ and pulse duration of $5 \mathrm{~ns}$. Elastic backscatter lidar profiles at $532 \mathrm{~nm}$ data and air mass modelling trajectories were used in order to evaluate the relationship that trace-element variability has with seasalt transport and biomass-burning apportionment. The lidar backscatter profiles can provide information about the vertical distribution of aerosol layers. By combining those data with the air mass trajectories, it is possible to infer the local sources and transport times for the aerosol plumes to arrive at the SPMA. The retrieval of the aerosol optical properties is based on the measurements of the light backscattered by aerosols, which allows us to obtain the aerosol backscatter coefficient $\left(\beta_{a}(\lambda, z)\right.$, where $\beta_{\text {aer }}$ is the aerosol backscatter and $z$ is the altitude) at $532 \mathrm{~nm}$. The determination of the vertical profile of the aerosol backscatter and extinction coefficients $\left(\alpha_{a}(\lambda, z)\right)$ relies on the lidar inversion technique following the Klett-Fernald-Sasano algorithm (Klett, 1981, 1983; Fernald, 1984; Sasano and Nakane, 1984) under the assumption of the single scattering approximation. To solve the lidar equation requires establishing a relationship between $\alpha_{a}(\lambda, z)$ and $\beta_{\text {aer }}(\lambda, z)$. This is typically achieved by assuming that the aerosol extinction-to-backscatter ratio is independent of altitude that $(\lambda)=\alpha_{\mathrm{aer}}(\lambda, z) / \beta_{\mathrm{aer}}(\lambda, z)$. To derive the appropriate values of the vertical profile of aerosol backscatter coefficient in the lower troposphere, we use an iterative inversion approach that tunes the LR values based on the inter-comparison of the aerosol optical depth (AOD) (Marenco et al., 2002) values derived from the lidar and collocated AERONET (Aerosol Robotic Network) sunphotometer data (Holben et al., 1998) or in some cases from Aqua and Terra Satellite Moderate Resolution Imaging Spectroradiometer (MODIS) data (Remer et al., 2005).

Air-mass trajectories are computed using the Global Data Assimilation System (GDAS), an operational system from the National Weather Service National Centers for Environmental Prediction. The GDAS is used as an input in the HYSPLIT model (version 4.8). Forward or backward trajectories are selected on a case-by-case basis, and the model vertical velocity option is chosen (Draxler and Hess, 2003). These trajectories provide the source of air masses arriving at the MASP at different levels (altitudes) and preset time intervals, with the coordinates of the IAG, where the instruments are installed, constituting a starting point.

\section{Results and discussion}

\subsection{Meteorological parameters, $\mathrm{CCN}$ and PNC}

This study was conducted in the winter, when the climate is mostly dry, although three rain events were observed during the study period. Meteorological parameters, PNC and $\mathrm{CCN}$ counts are presented in Table 1. As can be seen, the mean temperature was highest on day 5 , whereas it was lowest on days 7 and 8, with the greatest variation in temperature $\left(16.1^{\circ} \mathrm{C}\right)$ occurring on day 11 . The mean relative humidity $(\mathrm{RH})$ was above $70 \%$ on all days except days 4 and 5 , when it was 62 and $58 \%$, respectively. The greatest variation in RH occurred on days 3, 4 and 11. Precipitation events were observed in the morning on day 6 , and at night on days 11 and 13 (Fig. 2a). Figure 2 shows hourly variations in meteorological variables (temperature, $\mathrm{RH}$ and precipitation), CCN and PNC. The PNCs were highest between 07:00 and 19:00 LT, whereas they were lowest between 19:00 and 07:00 LT (Fig. 2b), hereafter referred to as the daytime and nighttime periods, respectively. During the daytime period, PNCs were elevated, especially during the rush hours, which are primarily associated with vehicular emissions. However, $\mathrm{CCN}$ peaks showed the opposite behavior, CCN concentrations being higher during the afternoon and the nighttime period. These patterns are discussed further in Sect. 3.4. As expected, periods of precipitation were characterized by lower PNCs and CCN concentrations. To eliminate possible interference with the data analysis, we excluded CCN and PNC values for the periods of precipitation. The diameter peaked at less than $100 \mathrm{~nm}$ and presented a mean value of approximately $55 \mathrm{~nm}$ for all days. The mean peak diameter was highest $(92 \mathrm{~nm})$ on day 6 and lowest $(29 \mathrm{~nm})$ on day 14, characterizing Aitken mode (25-100 nm) (Dal Maso et al., 2005). The mean PND was 44 and $62 \mathrm{~nm}$ for the daytime and for nighttime periods, respectively, the difference being attributed to the high PNCs during the morning hours. The particle size distributions and NPF events are discussed in Sect. 3.2.

To compare our PNC and CCN values with those of other studies, we plotted our results against the results of recent studies conducted in other urban regions (Fig. 3, Table S1 in the Supplement). The PNCs were higher during the daytime period than during the nighttime period, whereas $\mathrm{CCN}$ concentrations were comparable between the two periods. The higher PNCs during the daytime period were expected, given the increased emission of pollutants from local sources such as vehicular traffic. However, the fact that $\mathrm{CCN}$ concentrations did not vary significantly between the nighttime and daytime periods indicates that $\mathrm{CCN}$ formation was more efficient during the nighttime period. In a study conducted in Beijing, Gunthe et al. (2011) reported similar behaviour 


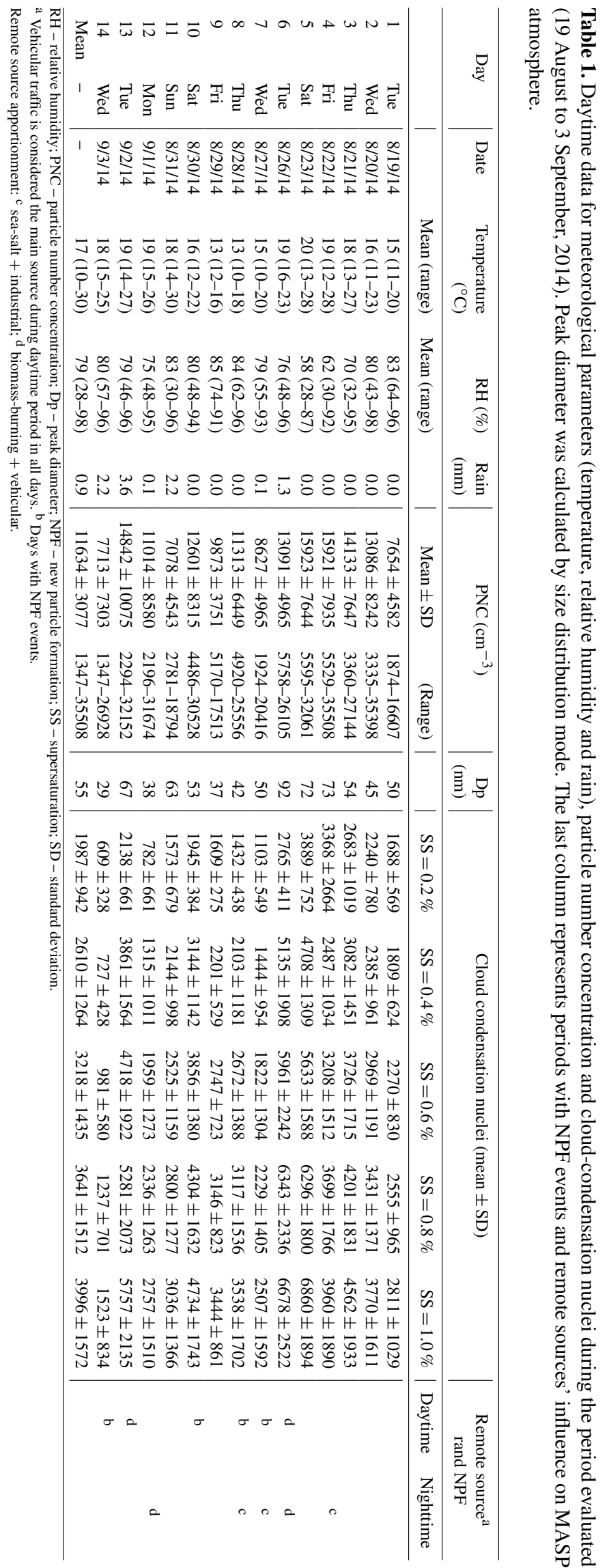




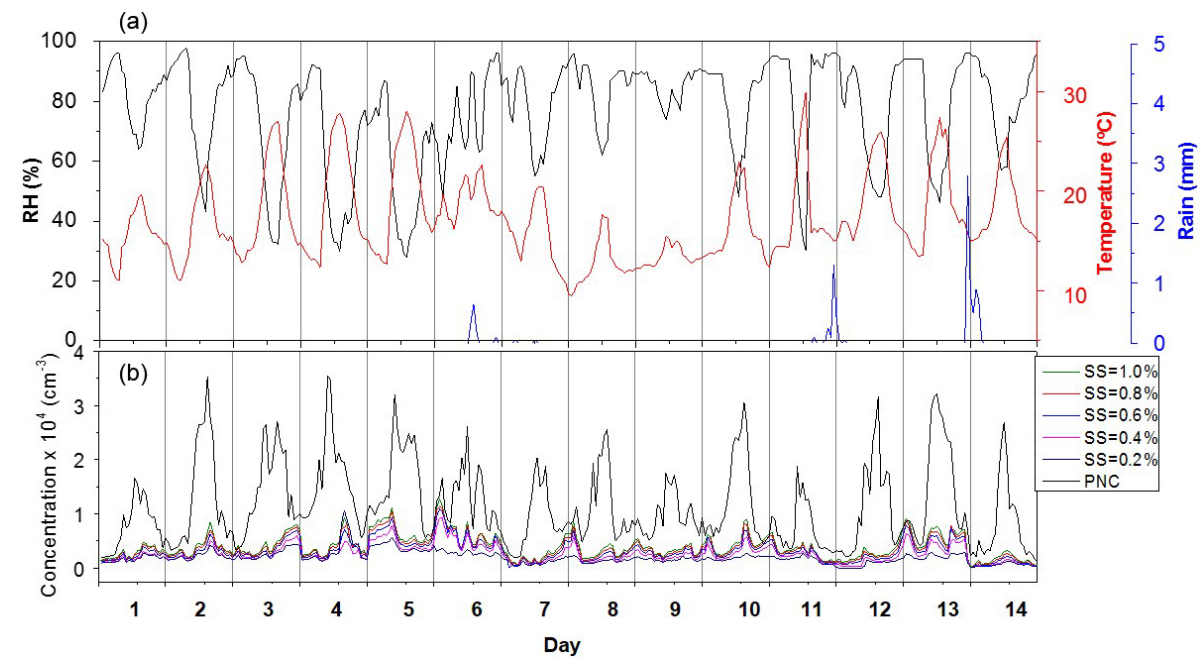

Figure 2. Hourly variability in (a) meteorological parameters such as relative humidity (RH), temperature and rainfall, and also for (b) particle number concentration (PNC) and cloud condensation nuclei $(\mathrm{CCN})$ for the period studied. Note that the PNC corresponds to a size distribution of 9-1000 nm, whereas the CCN correspond to a size distribution of $10-2500 \mathrm{~nm}$.

for fresh pollutant emissions and regional aged pollution, the latter presenting higher efficiency for $\mathrm{CCN}$ formation, as evidenced by lower PNCs and higher CCN concentrations. Those observations are supported by Köhler theory predictions, related to the greater efficiency of larger particles in $\mathrm{CCN}$ formation, which is extensively discussed in Sect. 3.4.

The overall mean PNC and CCN values obtained in the present study were similar to those observed by Almeida et al. (2014) for the MASP during October 2012. However, our PNC values were lower than those reported for the MASP by Backman et al. (2012) for October 2010 and January 2011. This variability can be attributed to different meteorological conditions, seasonal differences and the decrease in $\mathrm{SO}_{2}$ emissions associated with the recently mandated reduction in sulphur concentrations in diesel fuel (Kumar et al., 2016; CETESB, 2015). In a study conducted in Shanghai, Leng et al. (2013) reported PNC values similar to those obtained for the SPMA in the present study, although the CCN concentrations reported by those authors were higher; that might be related to the coastal environment, which increases the concentrations of most soluble compounds, such as ionic species $\left(\mathrm{SO}_{4}^{-2}, \mathrm{NO}_{3}^{-}, \mathrm{Na}^{+}, \mathrm{Cl}^{-}, \mathrm{K}^{+}\right)$, in the aerosol chemical composition. Our results showed PNC values similar to those observed for London and Madrid (Reche et al., 2011; GómezMoreno et al., 2011, respectively). In these three urban areas (London, Madrid and the MASP), transport emissions constitute the main pollution source and there are light industries around urban regions. London and Madrid have higher population densities than the MASP. However, the vehicle fleet in the MASP is larger than that in any of the other urban regions evaluated, although Madrid has the highest vehicle/inhabitant ratio and the highest proportion of dieselpowered vehicles $(\sim 50 \%)$. With a population of over 20 mil-

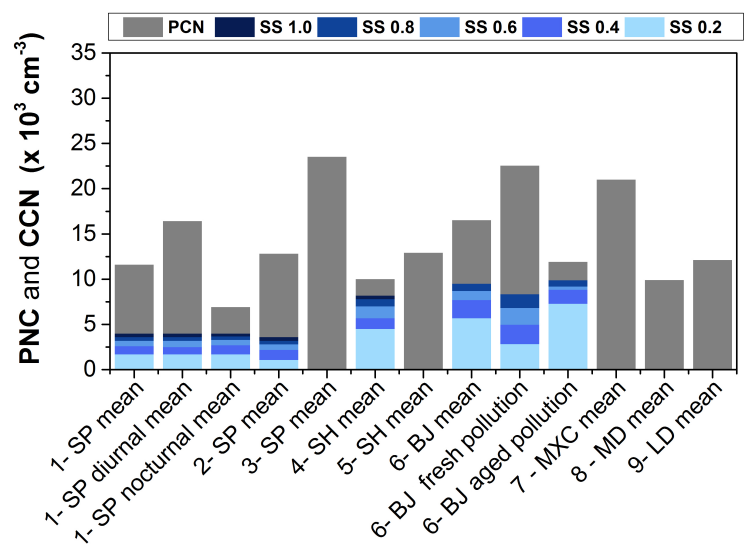

Figure 3. Comparison between particle number concentration (PNC) and cloud condensation nuclei $(\mathrm{CCN})$ values obtained in this study and in previous studies. All studies were carried out at urban background monitoring sites, where measurements were made on rooftops of buildings located some kilometers from the downtown areas. In the case of Toronto, the measurements were carried in the downtown area of the city. Detailed information is available in the Supplement in Table S1. SP - São Paulo; SH - Shangai; BJ - Beijing; MXC - Mexico City; MD - Madrid; LD - London; 1 - the present study; 2 - Almeida et al. (2014); 3 - Backman et al. (2012); 4 - Leng et al. (2013); 5 - Peng et al. (2014); 6 - Gunthe et al. (2011); 7 - Kalafut-Pettibone et al. (2011); 8 - Gómez-Moreno et al. (2011); 9 - Reche et al. (2011).

lion, Mexico City is the largest megacity in North America. Although comparable to the MASP, the mean PNC for Mexico City in 2006 was double that reported for the 2012-2014 period in the MASP (Kalafut-Pettibone et al., 2011; Almeida et al., 2014; This study). Nevertheless, the mean PNC re- 


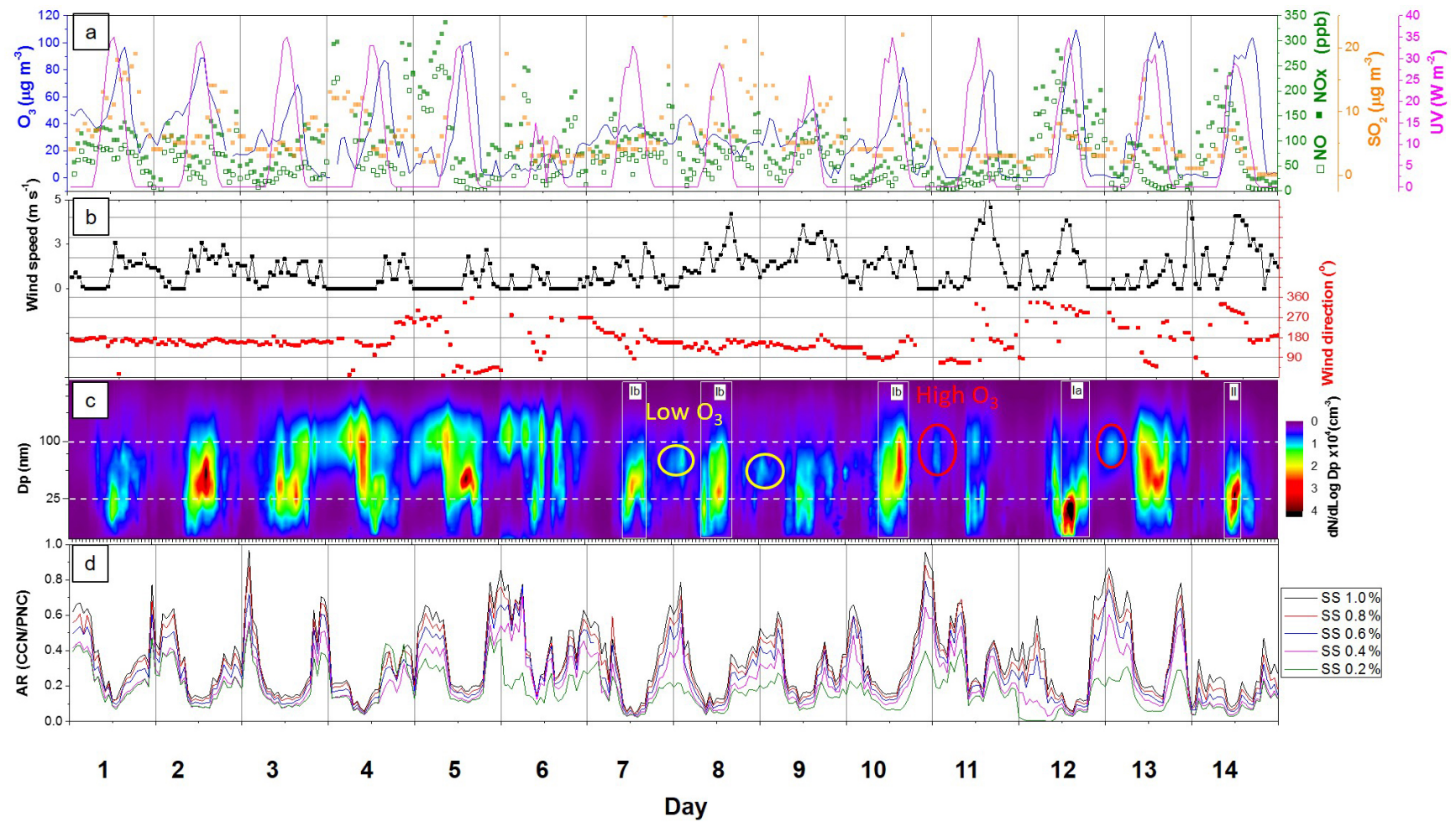

Figure 4. Hourly variability for (a) UV radiation, together with concentrations of $\mathrm{SO}_{2}, \mathrm{NO}_{x}, \mathrm{NO}_{2}$ and $\mathrm{O}_{3}$; (b) wind direction and speed; (c) particle number distribution (yellow and red circles indicate conditions of low- and high- $\mathrm{O}_{3}$ concentrations, respectively); and (d) activation ratio (AR), representing the cloud condensation nuclei / particle number concentration (CCN / PNC) ratio. UV radiation data, as well as the concentrations of $\mathrm{SO}_{2}, \mathrm{O}_{3}, \mathrm{NO}_{x}$ and $\mathrm{NO}_{2}$, were provided by the São Paulo State Environmental Protection Agency.

ported for Mexico City was similar to that observed for 2010 in the MASP (Backman et al., 2010). As previously mentioned, the lower PNCs in the MASP can be attributed to legislation that mandated a reduction in the concentration of sulphur in diesel fuel. The CETESB reported a $\sim 10 \%$ reduction in the emission of particulate matter from dieselpowered vehicles between 2010 and 2015. In the MASP, such vehicles emitted $26 \%$ of all particulate matter attributed to anthropogenic sources during 2015 (CETESB, 2015). In the case of Mexico City, $50 \%$ of all particulate emissions in 2006 were from diesel-powered vehicles (Kalafut-Pettibone et al., 2011).

\subsection{Daytime PND variability and NPF events}

Figure 4a shows the variability in UV radiation intensity, as well as in the concentrations of $\mathrm{SO}_{2}, \mathrm{O}_{3}, \mathrm{NO}$ and $\mathrm{NO}_{x}$. The gaseous concentrations measured at the four CETESB stations were selected according to the direction of the prevailing winds. For the most part, the daytime periods presented high UV intensity $\left(\sim 30 \mathrm{~W} \mathrm{~m}^{-2}\right)$ and $\mathrm{O}_{3}$ concentrations (80$100 \mu \mathrm{g} \mathrm{m}^{-3}$ ). On days 4, 5, 6, 12 and 14, $\mathrm{NO}$ and $\mathrm{NO}_{x}$ concentrations were elevated (100-420 ppb), which was mainly associated with vehicular emissions and prevailing winds from the northwest and northeast. The Marginal Pinheiros and Marginal Tietê roadways are approximately 1 and $4 \mathrm{~km}$, respectively, from the sampling site. In 2014, approximately $80 \%$ of total $\mathrm{NO}_{x}$ emissions in the MASP were attributed to vehicular traffic (CETESB, 2015). Figure 4a also shows that the higher $\mathrm{O}_{3}$ concentrations were preceded by $\mathrm{NO}_{x}$ peaks. This pattern was expected, given the chemical reactions that occur between $\mathrm{NO}_{x}$ and VOCs in the presence of UV radiation, which induces photochemical activity and the formation of secondary pollutants such as $\mathrm{O}_{3}$ and SOAs (Monks et al., 2015).

Sulphate and nitrate compounds, which are formed by $\mathrm{SO}_{2}$ and $\mathrm{NO}_{x}$ precursors, are important components of the nucleation process. The $\mathrm{SO}_{2}$ concentrations measured at CETESB stations were plotted according to wind direction in order to represent air masses arriving at the measurement site (Fig. 4a). The highest concentrations of $\mathrm{SO}_{2}$ were associated with winds from the southeast (Congonhas station), whereas winds from the north were associated with lower $\mathrm{SO}_{2}$ concentrations. To the southeast, there are two large industrial areas that represent an important source of $\mathrm{SO}_{2}$ (Fig. 1). During 2014, industrial activities accounted for $56.9 \%$ of the sulphur oxides emitted in the MASP. The $\mathrm{SO}_{2}$ transport from industrial areas is supported by some studies, which showed that marine air masses and industrial emissions from Cubatão 
reached the MASP. Sea-salt transport is discussed further in Sect. 3.3, based on the PMF and trajectory analyses.

In order to identify NPF events, we adopted the following requirements described by Dal Maso et al. (2005), which have been extensively employed in other studies (Backman et al., 2012; Betha et al., 2013; Ma and Birmili, 2015): a distinctly new particle mode (nucleation mode, particle diameters $<25 \mathrm{~nm}$ ) must appear in the size distribution; and the new mode must present a duration of several hours and show growth over time. These requirements were complemented by Ma and Birmili (2015), who stated the following: a sudden increase in PNC, above nighttime background concentration, must occur in nucleation mode, the burst must be sustained for a minimum of $1 \mathrm{~h}$ and a decrease in the concentration of the nucleation mode particles is expected at end of day.

Dal Maso et al.(2005) identified two classes of NPF events, the first of which is divided into two subclasses: (Ia) a clear and pronounced particle formation event, followed by particle growth; (Ib) a particle formation event in which particle growth can be observed from the nucleation, although without a clear nucleation burst; and (II) a particle formation event in which particle growth from nucleation mode cannot be determined.

The contour of the PNDs was plotted in order to identify and classify NPF event days (Fig. 4c). An NPF event meeting all of the requirements described above was observed on day 12 . The nucleation burst presented a duration of $3 \mathrm{~h}$, followed by particle growth until the beginning of the nighttime period, when a brief decrease in the concentration was observed. An NPF event occurring on day 14 was classified as class II because there was no significant particle growth after nucleation. That event presented nucleation bursts similar to those observed in Singapore by Betha et al. (2013) and in Brisbane, Australia, by Cheung et al. (2011). Those authors associated the events with winds from industrial areas, which carried large quantities of $\mathrm{SO}_{2}$ and VOCs. There were also NPF events on days 7, 8 and 10, all of those events being categorized as class $\mathrm{Ib}$, clearly showing particle growth throughout the daytime period. On those days, moderate to high concentrations of $\mathrm{SO}_{2}\left(5-20 \mu \mathrm{g} \mathrm{m}^{-3}\right)$ were observed at the Congonhas station, which suggests that the nucleation process began near that station, followed by the detection of particle growth at the USP station. Backman et al. (2012) observed similar class Ib events in the MASP.

The nucleation of primary aerosol occurs near local sources such as vehicular and industrial emissions. No nucleation events of that type were detected in the present study because of the distance between the sources and measurement site. However, five different secondary aerosol NPF events were identified. The class Ia and II events were mostly associated with high concentrations of $\mathrm{NO}_{x}$ and $\mathrm{O}_{3}$, as well as with photochemical activity, whereas the class Ib events were characterized as NPF passing through the measurement site only after the initiation of the event. The impact that those NPF events have on the AR (Fig. 4d) and on $D_{\text {act }}$ are discussed in Sect. 3.4.

As previously mentioned, $\mathrm{O}_{3}$ plays a fundamental role in SOA formation via VOC oxidation, its concentrations being indicative of the efficiency of the photochemical process (Sorribas et al., 2015). However, after the nucleation process, SOAs drive particle growth to larger sizes, primarily by condensation of non-volatile molecules (Pierce et al., 2012; Donahue et al., 2013). In addition, the particle growth rate is the most important factor in determining the extent to which new particles become CCN during NPF events (Leng et al., 2013). As can be seen in Fig. 4a and c, the NPF events observed on days 7 and 8 occurred at low $\mathrm{O}_{3}$ concentrations, whereas those observed on days 10, 12 and 14 occurred at high $\mathrm{O}_{3}$ concentrations. To assess the importance of photochemical activity and SOA production to particle diameter and to the $\mathrm{AR}$, we plotted NPF events under low and high $\mathrm{O}_{3}$ concentrations (Fig. S1 in the Supplement). As expected, particles formed during low- $\mathrm{O}_{3} \mathrm{NPF}$ were smaller than those formed during high- $\mathrm{O}_{3} \mathrm{NPF}$ (Fig. 4c). In addition, the AR was higher for the particles formed during high- $\mathrm{O}_{3}$ NPF than for those formed during low- $\mathrm{O}_{3}$ NPF. That is in agreement with the findings of studies predicting or demonstrating the efficiency of SOA condensation in inducing particles to become CCN (Pierce et al., 2012; Riipinen et al., 2011)

We drew PND contour plots in order to evaluate particle nucleation and growth progression during NPF events of the various classes and even on non-NPF event days. The proportional distribution of hourly PNCs in three modes (nucleation, Aitken and accumulation, 100-1000 nm) was also plotted, as were the hourly PNDs (Fig. 5). The NPF event on day 12 showed a nucleation burst between 10:00 and 15:00 LT (Fig. 5a), which was confirmed by the fact that the proportion of particles in nucleation mode was higher $(>50 \%)$ during that period than at any other time on that day. The particle growth in subsequent hours was accompanied by an increase in the proportion of particles in Aitken mode, as can be noted in the hourly PNCs and PND (Fig. 5a).

The class Ib NPF events showed characteristic particle growth after midday, with probable occurrence of a nucleation event, which was not observed between 10:00 and 12:00 LT. That particle growth was also detected by a higher PNC $(63 \%)$ of Aitken mode at 15:00 LT and an increase in peak diameters between 12:00 and 15:00 LT (Fig. 4b). It is noteworthy that the proportion of particles in Aitken was high ( $>45 \%$ ) for most hours on the three selected days, which indicates a continuous increase in the size of primary and new particles. This observation is supported by the fact that the local traffic presents constant emissions, with high density during the daytime period and low density during the nighttime period, which agrees with the total PNC values shown in the hourly frequency graphics (Fig. 5). 

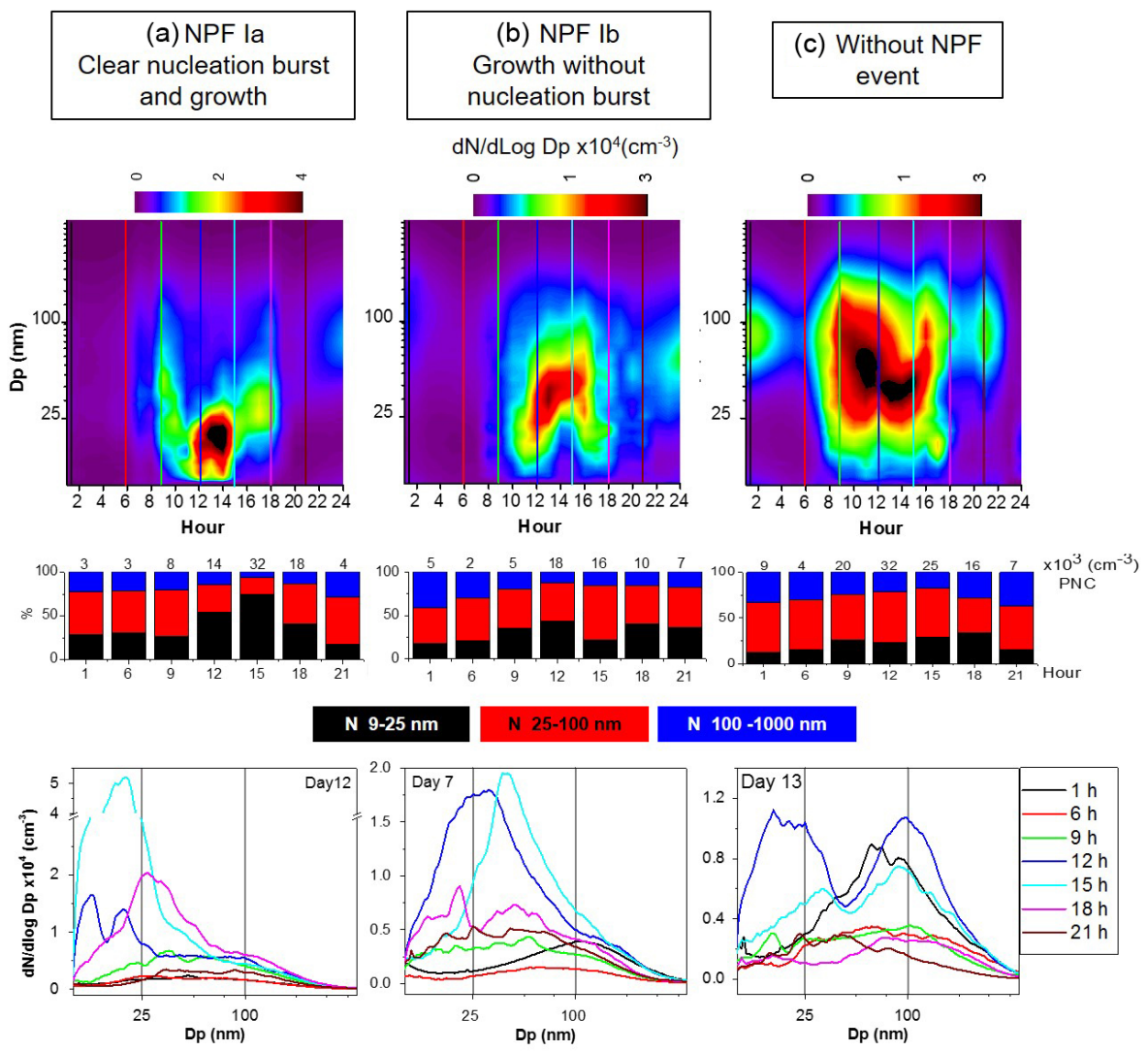

Figure 5. Particle number distribution (PND) contour plots for days with (a) new particle formation (NPF) events categorized as class Ia; (b) class Ib NPF events; and (c) no NPF events. The hourly bars show the proportions of particle number concentrations (PNCs) in three modes (nucleation, Aitken and accumulation) and hourly line graphs show PND distribution. Selected hours were marked on the PND contour plots in order to compare them with the hourly PND line graphs.

\subsection{Apportionment of vehicular traffic, biomass burning and sea salt from remote sources}

A combination of lidar, HYSPLIT trajectory, size-distributed chemical composition and PMF analysis $(\mathrm{Na}, \mathrm{Ni}, \mathrm{Cr}, \mathrm{Ca}, \mathrm{Ti}$, $\mathrm{K}, \mathrm{Cl} \mathrm{P}, \mathrm{Fe}, \mathrm{Mn}, \mathrm{Pb}, \mathrm{Cu}, \mathrm{Zn}, \mathrm{S}$ and $\mathrm{BC}$ ) analyses were used in order to apportion the contribution of sea salt and biomass burning within the air masses arriving at the MASP. Over the past 30 years, various studies conducted in the MASP have employed receptor modeling and aerosol chemical composition analysis in order to identify the main sources of atmospheric pollutants (Bouéres and Orsini, 1981; Andrade et al., 1994; Castanho and Artaxo, 2001; Sanchez-Ccoyllo and Andrade, 2002; Sanchez-Ccoyllo et al., 2008; Andrade et al., 2012). Those studies have determined that vehicular traffic account for $50-60 \%$ of fine particles, thus constituting the main source, followed by oil boilers (accounting for 20$40 \%$ ), road dust (accounting for 10-30\%), industrial emissions (accounting for 10-20\%), biomass burning (accounting for 10-20\%) and construction activities (accounting for $\sim 10 \%$ ). Some studies carried out in the MASP evaluated the elemental profiles of the principal urban pollution sources, characterizing observed elements such as $\mathrm{Mn}, \mathrm{Pt}, \mathrm{Ni}, \mathrm{Cu}, \mathrm{Cr}$ and $\mathrm{Zn}$ as markers of gasoline and alcohol emissions (Silva et al., 2010). Diesel burning by heavy-duty vehicles is associated mainly with BC and S. Suspended road dust, characterized inside and outside road tunnels, has been found to be comprised of $\mathrm{BC}, \mathrm{Si}, \mathrm{Al}, \mathrm{Fe}, \mathrm{Ca}, \mathrm{Mg}, \mathrm{K}$, Ti and $\mathrm{S}$, which denotes a mixture of soil, pavement abrasion, tire wear, brake wear and vehicular emission (Hetem and Andrade, 2016). In a general approach, other studies found $\mathrm{BC}$ to be related to biomass burning, $\mathrm{Na}$ and $\mathrm{Cl}$ to be related to sea-salt contribution, and $\mathrm{Fe}, \mathrm{Cu}, \mathrm{Zn}, \mathrm{Cr}, \mathrm{Pb}$ and $\mathrm{Ni}$ to be related to industrial emissions (Bzdek et al., 2012; Calvo et al., 2013; Taiwo et al., 2014).

Figure 6 shows the mass size distributions of trace elements from MOUDI membrane samples for different periods. The concentrations of $\mathrm{BC}$ were high $(\sim 0.9 \%)$ on days 6,12 and 13 (Fig. 6a), whereas they were intermediate $(\sim 0.4 \%)$ on days $7,8,9$ and 14 . The concentrations of $\mathrm{Cl}, \mathrm{K}$ and $\mathrm{Pb}$ were high on days 8 and 9 (Fig. 6b-d), and the concentration of $\mathrm{K}$ was intermediate $\left(\sim 0.2 \mu \mathrm{g} \mathrm{cm}^{-3}\right)$ on day 6. The elements $\mathrm{Ti}, \mathrm{Cr}, \mathrm{Ca}$ and $\mathrm{Cu}$ showed intermediate concentrations for most days, with peaks on days 6 and 


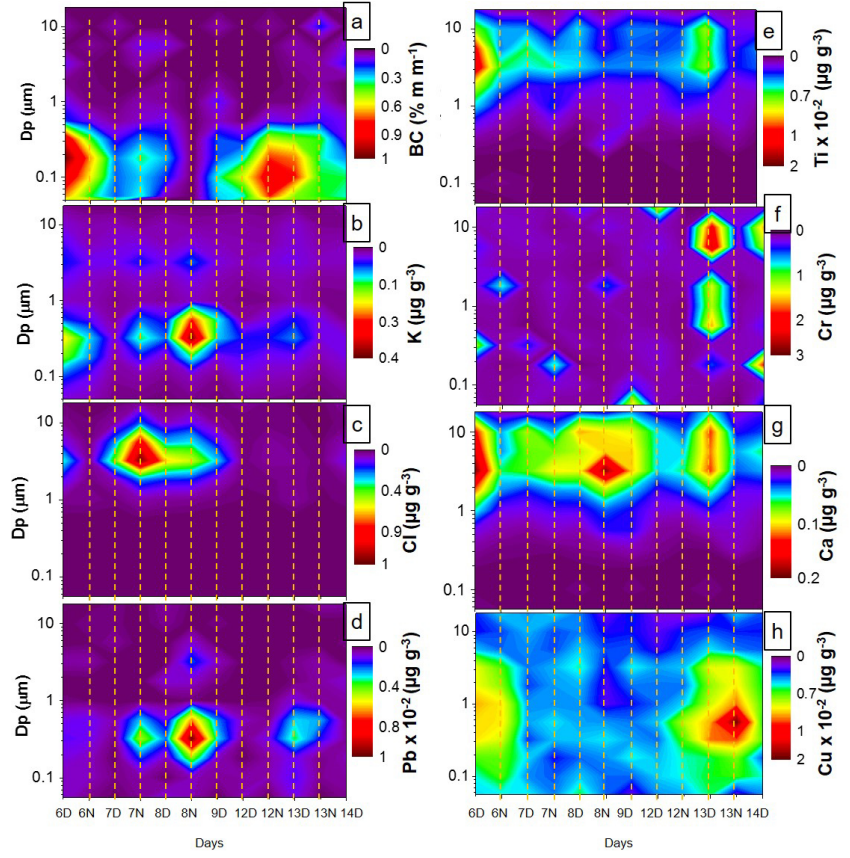

Figure 6. Mass size distribution of elemental concentrations of aerosol samples collected by Micro-orifice Uniform Deposit Impactor (a-h) during the daytime period (07:00-19:00 LT) and nighttime period (19:00-07:00 LT), represented by D and N, respectively. All sampling days were weekdays.

12 (Fig. 6e-h). In order to assess the source apportionment of aerosol mass concentration, a PMF analysis was applied to trace-element, $\mathrm{BC}$ and carbon monoxide $(\mathrm{CO})$ concentrations. The $\mathrm{CO}$ is an important marker associated with vehicular emissions in urban areas, its concentrations being measured at the Marginal Tietê. Our analysis showed that vehicular traffic had a great influence on all days, mainly during the daytime, and biomass burning had an influence only on days 6,12 and 13, whereas sea salt and industrial emissions had an influence only on days 7 and 8 (Fig. S4 in the Supplement).

Various studies have identified vehicular traffic as the main local pollutant source in MASP. The contribution of vehicular traffic is higher during the daytime and lower during the nighttime. Some species, such as $\mathrm{Cr}, \mathrm{Ti}, \mathrm{Cu}$ and $\mathrm{BC}$ are frequently used as markers for vehicular traffic (Andrade et al., 2012). In this study, those compounds showed a strong correlation with $\mathrm{CO}$ during daytime. We also observed that $\mathrm{BC}$ and $\mathrm{Cu}$ correlated strongly with $\mathrm{CO}$ during nighttime, as illustrated in Fig. S5 in the Supplement. In addition, the strong correlation between vehicular traffic marker species and CO confirms that vehicular traffic was the predominant daytime source on all days. The strong correlation of $\mathrm{BC}$ and $\mathrm{Cu}$ with $\mathrm{CO}$ at nighttime can be related to vehicular emission and biomass-burning events, as demonstrated by the PMF analysis.
Figure $7 \mathrm{c}$ and $\mathrm{d}$ present the vertical profile for two measurement days obtained with the MSP-Lidar I system. On day 6, several thin aerosol plumes were detected above the planetary boundary layer (PBL). According to the rangecorrected lidar signal (Fig. 7c), most of the aerosol load in the atmosphere is concentrated inside the PBL, approximately $500 \mathrm{~m}$ above ground level (a.g.l.). However, several aerosol layers can clearly be seen above the PBL, at 1000-2000 m a.g.l., and a thin aerosol layer can be seen at approximately $3000 \mathrm{~m}$ a.g.l. The mean aerosol backscatter profile at $532 \mathrm{~nm}$ (Fig. 7c), retrieved applying the Klett inversion method, as previously described, showed a peak of $0.006 \mathrm{~km}^{-1} \mathrm{sr}^{-1}$ at approximately $500 \mathrm{~m}$ a.g.l., representing all aerosol trapped inside the PBL, and another peak of $0.0018 \mathrm{~km}^{-1} \mathrm{sr}^{-1}$ at approximately $2800 \mathrm{~m}$ a.g.l. The mean aerosol vertical profile at $532 \mathrm{~nm}$ clearly shows a backscatter signal from aerosol plumes up to $4000 \mathrm{~m}$ a.g.l., which would typically be from a source outside the MASP.

When the lidar data were analyzed by tuning the LR values based on the inter-comparison of the MODIS-derived AOD, a mean lidar ratio of $70 \pm 14 \mathrm{sr}$ was obtained, which is within the range associated with absorbing particles from biomass burning (Müller et al., 2007; Baars et al., 2016). The air mass backward trajectories simulated using the HYSPLIT model (Fig. 7a) strengthens the hypothesis that aerosol from biomass burning was transported from the northern and central-west portion of Brazil, where there were several fire focusses, reaching higher levels and being transported to the MASP at altitudes of $3000-4000 \mathrm{~m}$ a.g.l. The same pattern was found for day 12 (Fig. 7d) and 13 (Fig. S6 in the Supplement), when thin aerosol plumes were also detected above the PBL at $2400-4000 \mathrm{~m}$ a.g.l., as can be seen in the mean backscatter profile (Fig. 7d). The mean lidar ratio for this case was also $70 \pm 14 \mathrm{sr}$, again associating the plumes with a biomass-burning aerosol type. Air-mass trajectories (Fig. 7b) indicated that plumes detected at the MASP by the lidar system had been transported from the central-west portion of the country and had traveled across regions with several fire focusses. The lidar data analyses were in agreement with the PMF analysis and size distribution of elemental concentrations in samples collected by MOUDI on days 6, 12 and 13, when high concentrations of $\mathrm{BC}$ were observed. In addition, the higher variability of $\mathrm{Cu}, \mathrm{Cr}, \mathrm{Ni}$ and $\mathrm{CO}$ concentrations on those days, obtained in the PMF analysis, indicates an association between biomass burning and vehicular emissions.

Previous studies have shown the contribution of sea salt to the aerosol profile in the MASP (Andrade et al., 1994; Castanho and Artaxo, 2001; Vara-Vela et al., 2016). As can be seen in Fig. 4b, the prevailing wind direction was from the southeast during the nighttime period on days 7 and 8 , which is in line with the low-altitude air-mass trajectories shown in Fig. S2 in the Supplement; the higher concentrations of $\mathrm{Na}$ and $\mathrm{Cl}$ indicate sea-salt transport from the coastal region, as evidenced by the increased $\mathrm{Pb}$ concentrations on those days. Normally, $\mathrm{Pb}$ is linked to emissions 

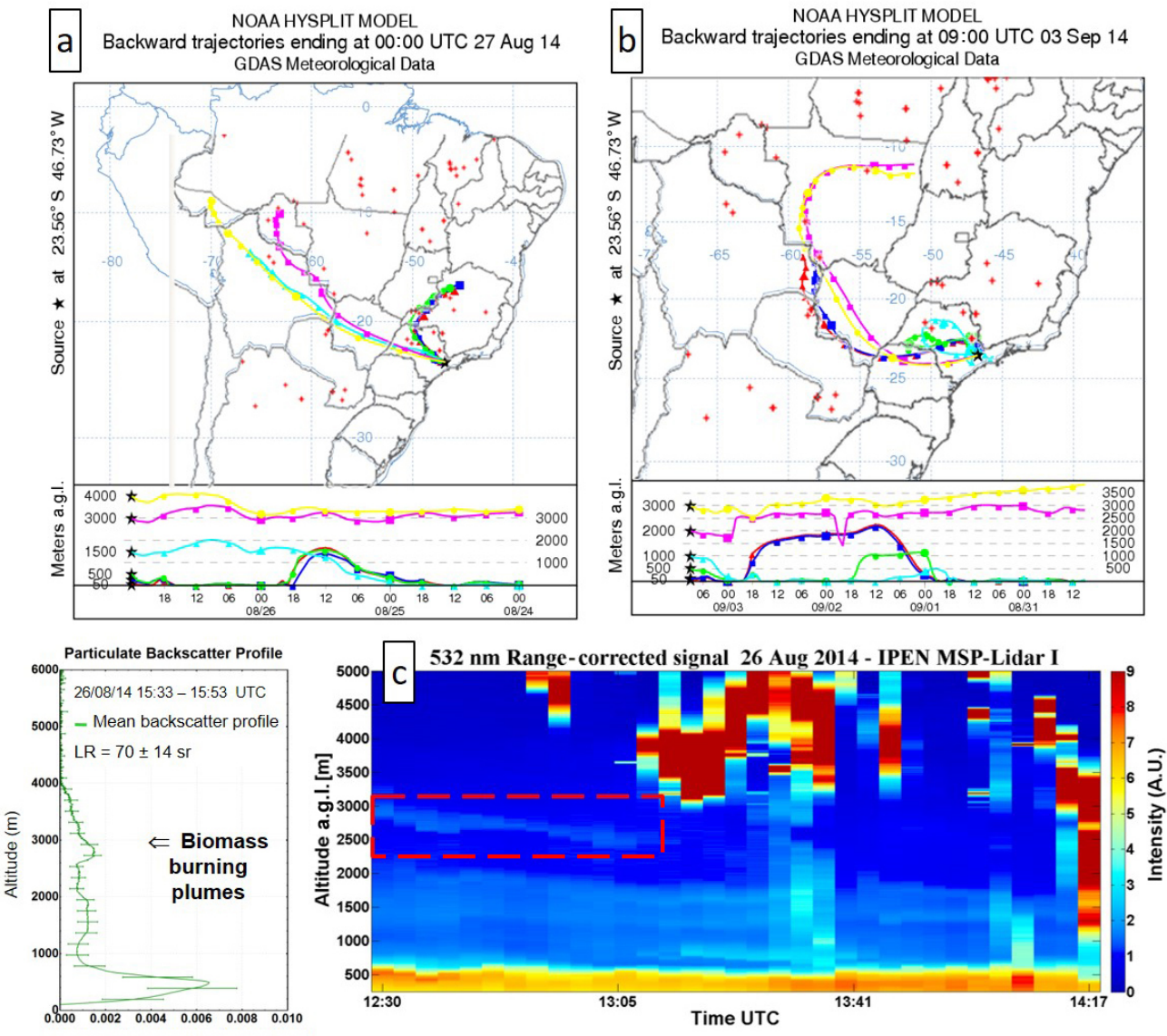

Backscatter coefficient $\left(\mathrm{km}^{-1} \mathrm{sr}^{-1}\right)$
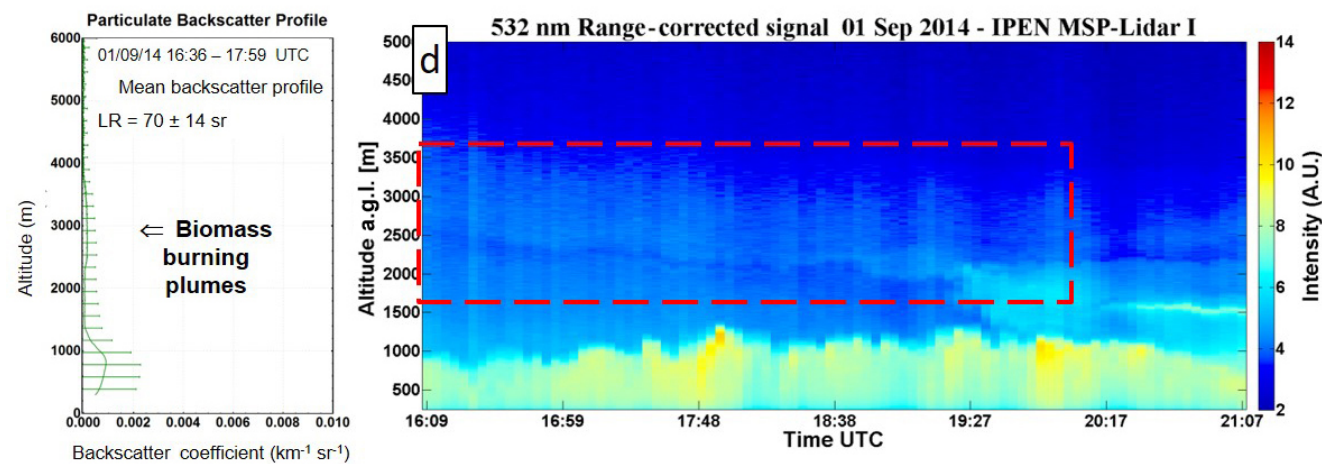

Figure 7. Trajectory and lidar analyses for days with biomass-burning events. (a, b) Hybrid Single Particle Lagrangian Integrated Trajectory (HYSPLIT) trajectory models and biomass-burning events for days 6, 7, 12, 13 and 14. (c, d) The particulate backscatter profile and lidar analyses for days 6 and 12, when the prevailing wind was from the north or northeast, where most biomass-burning events occur. The biomass-burning plumes were detected by lidar and Geostationary Operational Environmental Satellite. NOAA - (United States) National Oceanic and Atmospheric Administration; GDAS - Global Data Assimilation System; a.g.l. - above ground level; IPEN - Instituto de Pesquisas Energéticas e Nucleares ([Brazilian] Nuclear and Energy Research Institute); MSP-Lidar I - Lidar I of the Municipality of São Paulo; LR - lidar ratio.

from anthropogenic sources, mainly industrial emissions, as the contribution from fuel burning has decreased substantially after the ban on $\mathrm{Pb}$ in gasoline fuels. Using $\mathrm{Pb}$ isotopic signatures, Gioia et al. (2010) demonstrated that aerosols from the Cubatão industrial area arrive at the MASP when southeast wind predominates. As can be seen in Fig. 1, Cubatão is located in the coastal region, corroborating the seasalt transport. Figure 8c shows the range-corrected signal of the MASPMSP-Lidar I system in the atmosphere throughout day 4. Between 20:30 and 22:13 UTC, signal attenua- 

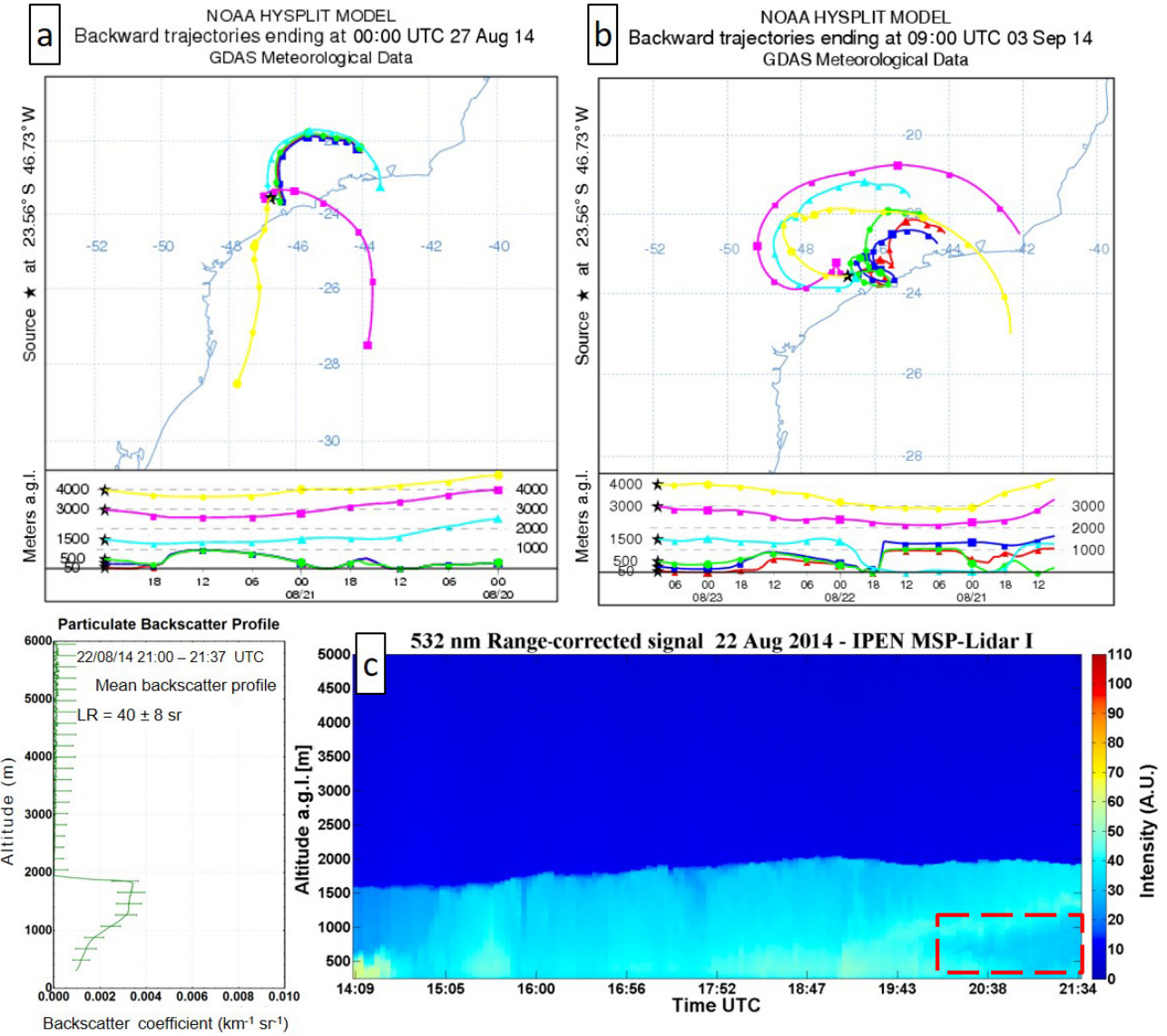

Figure 8. Trajectory and lidar analyses for days with sea-salt apportionment. (a, b) Hybrid Single Particle Lagrangian Integrated Trajectory (HYSPLIT) trajectory models for days 3,4 and 5. (c) Particulate backscatter profile and lidar analyses for days 3 and 4, when the prevailing wind was from the south, southeast or southwest (i.e., from the Atlantic Ocean and coastal regions). Sea-salt plumes were detected by lidar analysis on day 4, although higher confidence interval concentrations were observed on days 7 and 8. NOAA - (United States) National Oceanic and Atmospheric Administration; GDAS - Global Data Assimilation System; a.g.l. - above ground level; IPEN - Instituto de Pesquisas Energéticas e Nucleares ([Brazilian] Nuclear and Energy Research Institute); MSP-Lidar I - Lidar I of the Municipality of São Paulo; LR - lidar ratio.

tion was detected at $500-1000 \mathrm{~m}$ a.g.1., which is associated with the intrusion of clean air at the PBL of the MASP. Typically, such intrusion is related to sea breeze transported to MASP (Rodrigues et al., 2013). The mean backscatter profile showed the presence of aerosol only within the PBL, where a smaller aerosol backscatter signal could be seen between 300 and $1200 \mathrm{~m}$ a.g.l., associated with the clean-air region inside the PBL. The mean lidar ratio for this measurement was $40 \pm 8 \mathrm{sr}$, which is within the range associated with the urban aerosol type (Baars et al., 2016). These observations are corroborated by the PMF analysis, which shows sea-salt and industrial emissions contribution for days 7 and 8 associated with $\mathrm{Na}, \mathrm{Cl}, \mathrm{Pb}, \mathrm{Fe}, \mathrm{Zn}$ and $\mathrm{S}$.

In summary, sea-salt air masses arriving at the MASP were observed during the nighttime period on three of the days evaluated. During the nighttime periods of day 4, sea-salt events were observed by lidar, whereas they were identified by the PMF analysis using trace-element concentration dur- ing the nighttime period of days 7 and 8 . Throughout the year, sea breezes arrive at the MASP in the afternoon and evening (Oliveira et al., 2003; Freitas et al., 2007). In the present study, plumes generated from biomass burning were detected by lidar and PMF analysis on days 6, 12 and 13, being associated with vehicular traffic with an increase in BC and $\mathrm{CO}$ on those specific days. In Brazil, numerous biomassburning events occur every year from July to November, mainly in the central and northern regions of the country. However, many such events, associated with agricultural activities, occur within the state of São Paulo throughout the year (Kumar et al., 2016). All focus fires, as shown in Fig. 7a and $b$, were identified from Geostationary Operational Environmental Satellite images. In addition, vehicular traffic predominance during daytime could be observed, in line with several source apportionment studies carried out in MASP. 
Table 2. Comparison of mean activation ratio and particle number concentration (at different supersaturation levels) observed in this study and in other studies. In our study the values were separated for daytime and nighttime.

\begin{tabular}{|c|c|c|c|c|c|c|c|c|c|c|}
\hline \multirow[t]{2}{*}{ Reference } & & \multirow[t]{2}{*}{ Site } & \multirow[t]{2}{*}{ Environment } & \multirow[t]{2}{*}{ Details } & \multicolumn{5}{|c|}{ Activated ratio (CCN / PNC)* } & \multirow{2}{*}{$\begin{array}{r}\mathrm{PNC}\left(\times 10^{4}\right) \\
\mathrm{cm}^{-3}\end{array}$} \\
\hline & & & & & $0.20 \%$ & $0.40 \%$ & $0.60 \%$ & $0.80 \%$ & $1.0 \%$ & \\
\hline \multirow[t]{3}{*}{ This study } & Total mean & \multirow[t]{3}{*}{ Sao Paulo } & \multirow[t]{3}{*}{ Urban } & Entire campaign & $0.19 \pm 0.12$ & $0.24 \pm 0.16$ & $0.30 \pm 0.19$ & $0.35 \pm 0.20$ & $0.38 \pm 0.22$ & $1.2 \pm 0.77$ \\
\hline & Diurnal & & & - & $0.13 \pm 0.08$ & $0.16 \pm 0.09$ & $0.19 \pm 0.10$ & $0.22 \pm 0.11$ & $0.52 \pm 0.21$ & $1.6 \pm 0.78$ \\
\hline & Nocturnal & & & - & $0.24 \pm 0.12$ & $0.33 \pm 0.15$ & $0.41 \pm 0.18$ & $0.47 \pm 0.19$ & $0.24 \pm 0.12$ & $0.3 \pm 0.69$ \\
\hline \multicolumn{2}{|c|}{ Almeida et al. (2014) } & Sao Paulo & Urban & Entire campaign & $0.10 \pm 0.05$ & $0.19 \pm 0.09$ & $0.23 \pm 0.10$ & $0.26 \pm 0.11$ & $0.28 \pm 0.12$ & $1.3 \pm 0.54$ \\
\hline \multicolumn{2}{|c|}{ Andreae et al. (2004) } & Amazon & Forest & Green ocean & - & - & - & - & 0.68 & 0.05 \\
\hline \multicolumn{2}{|c|}{ Leng et al. (2013) } & Shangai & Urban/coast & Continental - marine & - & - & - & 0.4 and 0.6 & - & $0.5-1.0$ \\
\hline \multirow{3}{*}{\multicolumn{2}{|c|}{ Gunthe et al. (2011) }} & Beijing & Urban & Entire campaign & $0.41 \pm 0.21$ & $0.54 \pm 0.21$ & $0.60 \pm 0.23$ & $0.66 \pm 0.23$ & - & $1.7 \pm 0.4$ \\
\hline & & & & Aged pollution & $0.62 \pm 0.08$ & $0.74 \pm 0.08$ & $0.80 \pm 0.08$ & $0.84 \pm 0.06$ & - & $1.1 \pm 0.23$ \\
\hline & & & & Fresh city pollution & $0.15 \pm 0.12$ & $0.25 \pm 0.21$ & $0.34 \pm 0.24$ & $0.42 \pm 0.26$ & - & $1.2 \pm 0.37$ \\
\hline \multicolumn{2}{|c|}{ Burkart et al. (2011) } & Vienna & Urban & $\mathrm{SS}=0.5 \%$ & - & 0.13 & - & - & - & $0.9-5.4$ \\
\hline \multicolumn{2}{|c|}{ Sihto et al. (2011) } & Finland & Forest & - & - & $0.21-0.42$ & - & - & - & $\sim 0.2$ \\
\hline \multicolumn{2}{|c|}{ Yum et al. (2005) } & Korea & Urban/coast & Continental - marine & - & - & - & - & $0.43-0.74$ & $0.4-0.8$ \\
\hline \multirow{3}{*}{\multicolumn{2}{|c|}{ Furutani et al.(2008) }} & California & Urban/coast & Anthropogenic polluted & - & - & $0.4-0.6$ & - & - & $0.2-1.5$ \\
\hline & & & & Fresh Ship exaust & - & - & $0.06-0.2$ & - & - & $1.5-3.0$ \\
\hline & & Pacific Ocean & Over ocean & - & - & - & $0.6-1.0$ & - & - & $0.2-0.6$ \\
\hline
\end{tabular}

* $\mathrm{CCN}$ - cloud condensation nuclei; PNC - particle number concentration; SS - supersaturation.

\subsection{Effects of vehicular traffic, remote sources and NPF events on CCN activation properties}

The mean AR values were $0.22 \pm 0.05$ (at $0.2 \%$ ), $0.33 \pm 0.09$ (at $0.4 \%$ ), $0.41 \pm 0.05$ (at $0.6 \%$ ), $0.48 \pm 0.09$ (at $0.8 \%$ ) and $0.53 \pm 0.09$ (at $1.0 \%$ ), being nighttime means twice as high as the daytime means for all supersaturation levels (Table 2 and Fig. 9a). In addition, the PNC was five times higher during daytime than nighttime. Vehicular traffic was identified as the main daytime local pollutant source on all days. In order to determine the effects that NPF events have on ARs, the mean values were split into daytime (with vehicular traffic) and nighttime periods with and without NPF or remote source events (non-event), as seen in Fig. 9a. We observed a tendency for ARs to be lower during daytime with NPF than those without, although we observed no such tendency for nighttime periods. That is in agreement with the findings of previous studies, suggesting that larger particles act more efficiently as CCN than smaller particles (Sihto et al., 2011; Dusek et al., 2010). In a study conducted in Finland, some events featured NPF bursts, followed by particle growth. During those events, the ARs were very low, due to higher PNCs and smaller particle sizes (Sihto et al., 2011). In the present study, the AR increased substantially after each NPF event, although it was still lower than that observed on the non-event days. In addition, we observed increases in the number of CCN during the nighttime periods after NPF events, as showed in the Supplement (Fig. S3), attributed to the high rate of growth among the particles formed during $\mathrm{NPF}$, an observation that is supported by previous studies ( $\mathrm{Si}$ hto et al., 2011; Yue et al., 2011; Peng et al., 2014).

Figures $4 \mathrm{c}$ and 9 show the predominance of larger particles during the nighttime, as a result of primary and secondary aerosol growth during the daytime period. Therefore, the higher AR during nighttime was an expected finding, given the efficiency of larger particles to act as CCN. Dur-
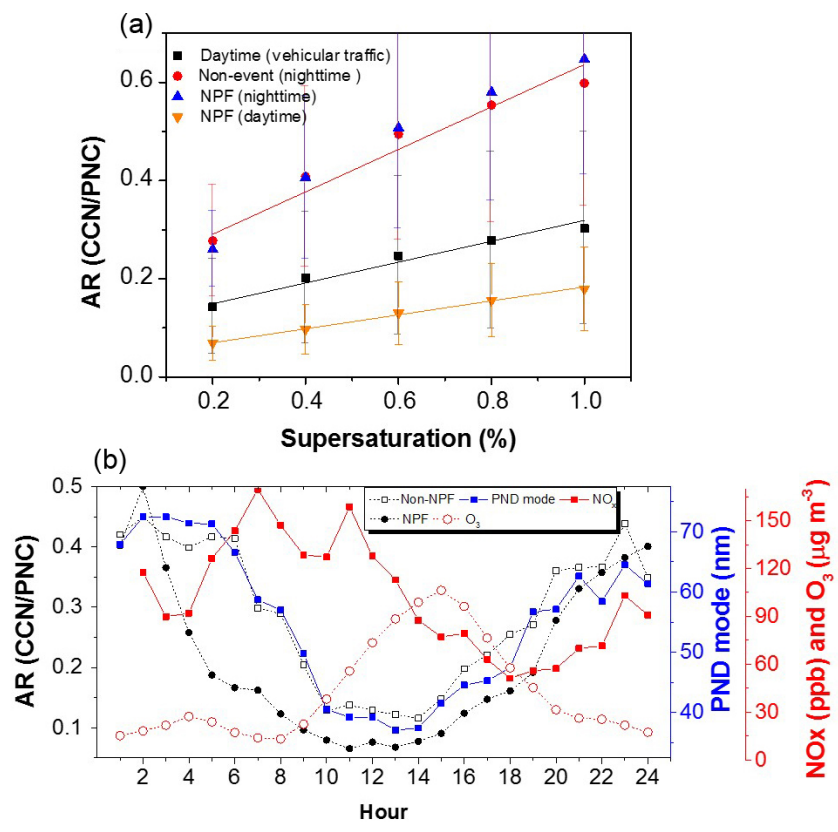

Figure 9. (a) Mean activation ratio (AR) for the daytime (vehicular traffic) and nighttime periods of days with and without new particle formation (NPF) events, by level of supersaturation. (b) Mean hourly AR (at a supersaturation of $0.4 \%$ ) on days with and without NPF events, plotted together with particle size mode, nitrogen oxides $\left(\mathrm{NO}_{x}\right)$ and $\mathrm{O}_{3}$ in order to evaluate the effect of vehicular emissions on particle size and AR. The AR values for nighttime and daytime showed clear differences, whereas days with NPF events presented slightly lower values than days without. Two processes contribute to particle size and AR decrease, namely primary aerosol from vehicular traffic $\left(\mathrm{NO}_{x}\right)$ and secondary NPF formed in the afternoon. PND - particle number distribution. 
ing the daytime vehicular traffic, the mean AR values were similar to those observed in other urban areas, although not to those observed in coastal areas (Leng et al., 2013; Furutani et al., 2008), as indicated by recent studies of fresh urban pollution conducted in the MASP, Vienna and Beijing (Almeida et al., 2014; Burkart et al., 2011; Gunthe et al., 2011). However, the AR reported for Beijing was twice that found for the MASP in the present study, considering the entire campaigns for both, although the PNC values were similar. In addition, the AR values observed for the SPMA in the present study are comparable to the fresh ship-exhaust emissions reported in a study conducted along the coast of California (Furutani et al., 2008). The nighttime AR values observed for the MASP were similar to those reported in a study conducted in a forest environment (Sihto et al., 2011) and in the coastal environments, although opposite those observed in other urban environments (Table 2). However, the mean nighttime $\mathrm{AR}$ and PNC values were higher for aged pollution in Beijing than for the MASP.

Figure $9 \mathrm{~b}$ shows the hourly mean AR values for days with and without NPF. The AR values were lowest between 10:00 and 15:00 LT, whereas they were highest during the nighttime period. The AR began to decrease after 06:00 LT and subsequently began to increase after 15:00 LT. In the MASP, the morning rush occurs between 07:00 and 10:00 LT, whereas the afternoon rush occurs between 17:00 to 20:00 LT. The decrease began, and the lower values of AR occurred, during the morning rush and formation of a secondary aerosol. Vehicular traffic and secondary aerosol formation constitute the main sources of particles in megacities such as the MASP (Andrade et al., 2012 and prior studies). As previously discussed, the formation of secondary aerosols is favored by photochemical reactions, which depend on solar radiation (UV and visible wavelength light), $\mathrm{O}_{3}$ and hydroxyl radicals. Figure 4a shows that $\mathrm{UV}$ radiation and $\mathrm{O}_{3}$ peak at midday, after which there is secondary aerosol formation and growth, as demonstrated by intermediate and high concentrations in nucleation and Aitken modes, respectively, in the afternoon (Fig. 4c).

The variability in $\mathrm{NO}_{x}$ and $\mathrm{CO}$ concentrations measured at the Marginal Tietê is mainly associated with vehicular traffic, because fuel combustion is the predominant source of such pollutants in the MASP. As can be seen in Figs. 9b and $10 \mathrm{c}$, an increase in $\mathrm{NO}_{x}$ occurred during the morning rush and was clearly related to the decrease in AR and particle diameter mode (Fig. 9b), as well as to the increase in $D_{\text {act }}$ (Fig. 10c). The $\mathrm{NO}_{x}$ decrease after midday was not associated with the decrease in traffic volume but with photochemical reactions and secondary formation of pollutants, as previously discussed. We believe that the $\mathrm{NO}_{x}$ and $\mathrm{O}_{3}$ variability corroborates our assumption, explaining the decrease in AR values during the daytime period in the presence of high vehicular traffic volume and secondary aerosol formation.

The increase in AR after 15:00 LT can be correlated with the increase in particle diameter and $\mathrm{CCN}$ concentrations. In addition, the production of SOAs by VOC degradation can result in the formation of polar functional groups that contribute to the growth and hydrophilicity of particles. Therefore, aged aerosols emitted and formed during the morning from vehicular traffic and secondary particles mainly showed an increase in $\mathrm{AR}$ at the end of the afternoon and during the nighttime period. This observation is in agreement with those of previous studies in which increased CCN activation was associated with aged anthropogenic emissions (Quinn et al., 2008; Furutani et al., 2008; Dusek et al., 2010; Bougiatioti et al., 2011; Zhang et al., 2014). Nevertheless, vehicular emissions from the afternoon rush (17:00-20:00 LT) had less effect on the AR than those from the morning rush, probably due to the absence of secondary aerosols and mixing with aged aerosols. The hourly particle diameter mode clearly shows the effect of particle size on AR values, lower ARs being accompanied by smaller particle size modes (Fig. 9b). Our observation is in agreement with those of previous studies demonstrating the strong effect of particle size on CCN activity.

The overall mean $D_{\text {act }}$ varied between $54 \mathrm{~nm}$ (at $\mathrm{SS}=1.0 \%$ ) and $155 \mathrm{~nm}$ (at $\mathrm{SS}=0.2 \%$ ) for the nighttime and daytime periods, respectively. A comparison between the $D_{\text {act }}$ values obtained in this study and those reported in the literature is shown in Table S2. As can be seen in Fig. 10a, $D_{\text {act }}$ presents a non-linear decrease as a function of an increase in supersaturation. The $D_{\text {act }}$ was higher during the daytime period than during the nighttime period, as was expected given the AR data. The mean $D_{\text {act }}$ values for daytime with vehicular traffic + biomass burning and vehicular traffic + NPF events were similar to those observed for those days with vehicular traffic only. The $D_{\text {act }}$ values for nighttime after NPF or during sea salt + industrial emissions events were similar to those observed after non-event days, although the $D_{\text {act }}$ values were slightly higher for nighttime during which there were biomass-burning plumes and vehicular traffic, mainly when the SS $<0.6 \%$. At high supersaturation values, particles with different chemical composition and therefore hygroscopicity have only a weak effect on CCN activity (Sihto et al., 2011; Zhang et al., 2014).

Figure $10 \mathrm{c}$ shows the time series of the mean $D_{\text {act }}$ values for days with and without NPF events. The $D_{\text {act }}$ values recorded during rush hours were higher on days with NPF than on those without. A number of hours before the occurrence of NPF events in which lower PNCs and larger particles predominated (Figs. 4c and 10c), lower AR values and higher $D_{\text {act }}$ values were observed (Figs. $9 \mathrm{~b}$ and 10c, respectively). This observation could be related to a possible increase in SOA precursor compounds in condensed phases before NPF events. Some of those compounds are monoterpenes and aromatic compounds, which have been reported to present low hygroscopicity (Kroll and Seinfeld, 2008). Apart from during the above-mentioned pre-NPF periods, days with and without NPF events showed similar nighttime means. 

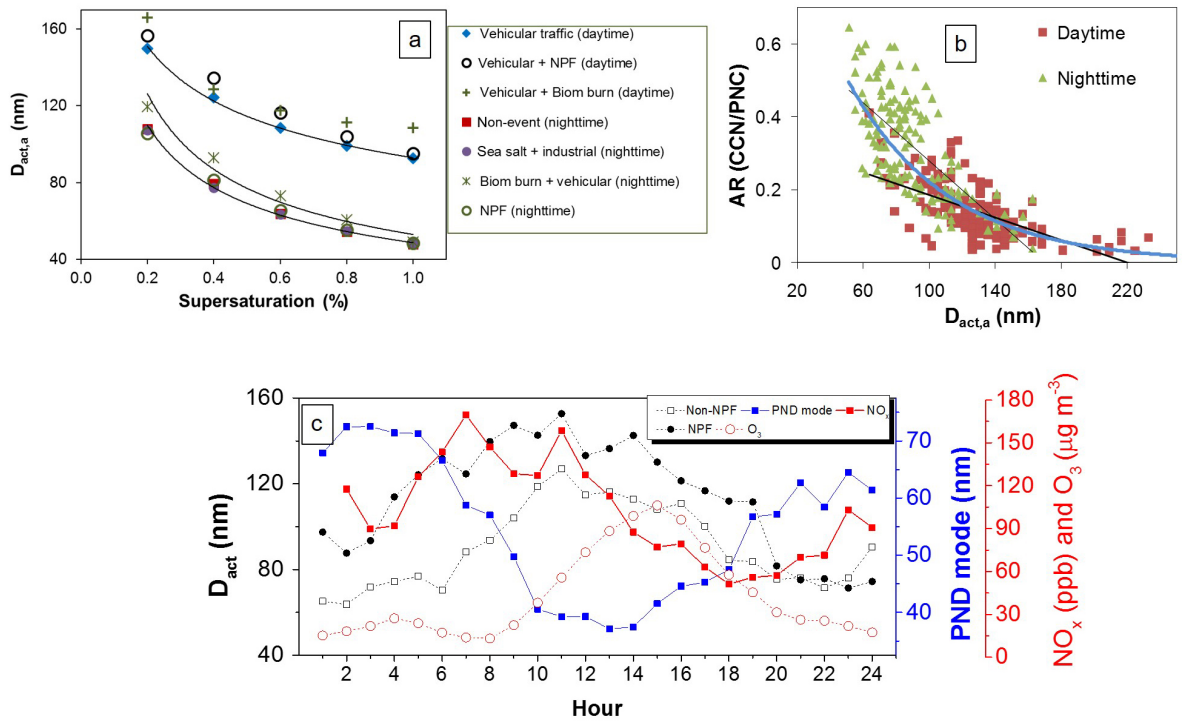

Figure 10. (a) Mean apparent activation diameter $\left(D_{\text {act }}\right)$ at various supersaturation levels, showing that it was highest at the lower levels of supersaturation. (b) Activation ratio (AR), in relation to the $D_{\text {act }}$ (c) Time series of $D_{\text {act }}$ on days with and without new particle formation (NPF) events, plotted together with particle size mode, $\mathrm{NO}_{x}$ and $\mathrm{O}_{3}$. The $D_{\text {act }}$ values were calculated for supersaturation of $0.4 \%$. Biom burn - biomass burning; PND - particle number distribution.

The efficiency of aerosol particles to act as CCN can be estimated on the basis of AR and $D_{\text {act }}$ data. The AR is dependent on particle size and chemical composition, whereas $D_{\text {act }}$ is dependent on chemical composition only (Furutani et al., 2008). As can be seen in Fig. 10b, the non-linear correlation between AR and $D_{\text {act }}$ can be related to different chemical composition and size distribution of aerosol. During daytime, the $D_{\text {act }}$ was increased and the AR was decreased, whereas the inverse was true for the nighttime. In general, the daytime period is associated with particles that are less hygroscopic and smaller, mainly emitted by vehicular traffic and formed in NPF events. However, the decreased $D_{\text {act }}$ and increased AR were observed in the nighttime period, being associated with larger and more hygroscopic particles. Our observations support the assumption that nighttime samples typically comprise greater concentrations of water-soluble species, such as $\left(\mathrm{NH}_{4}\right)_{2} \mathrm{SO}_{4}, \mathrm{SOA}$ and $\mathrm{NO}_{3}^{-}$, and of marine air than daytime samples. Our findings are also in keeping with those of other studies showing that aged aerosols present high hygroscopicity (Gunthe et al., 2011; Bougiatioti et al., 2011).

We compared the $D_{\text {act }}$ values obtained in this study with those reported in previous studies (Fig. 11 and Table S2). Our nighttime (non-event) means were similar to those reported for continental air masses over Shanghai (Leng et al., 2013), for the atmosphere over a boreal forest in Finland (Sihto et al., 2011) and for periods without air masses containing anthropogenic emissions over California (Furutani et al., 2008), as detailed in Table S2 in the Supplement. The mean $D_{\text {act }}$ values for non-event nighttime periods and during sea-

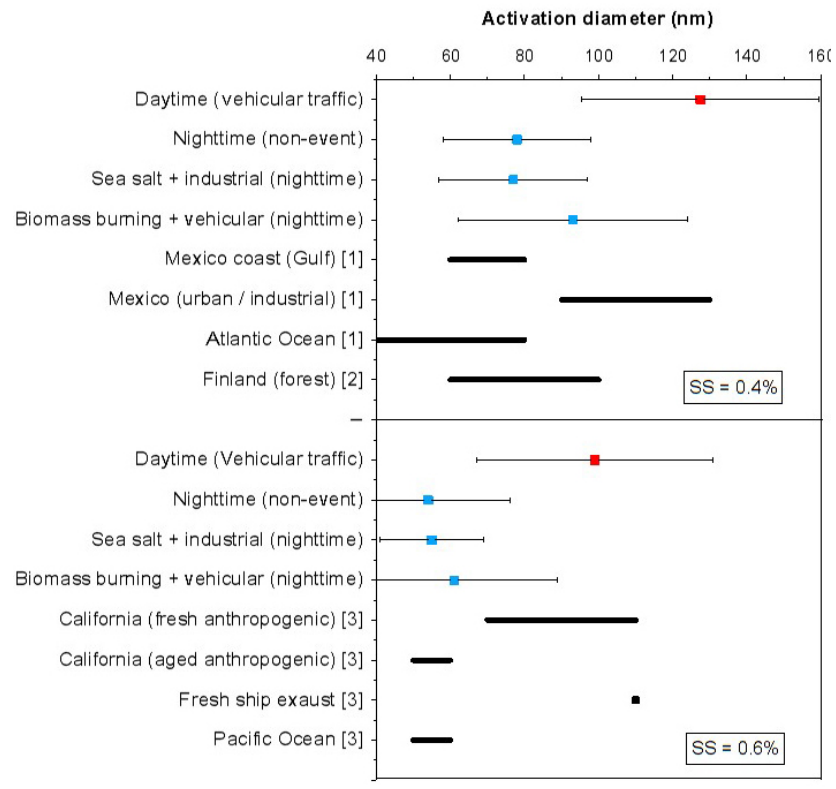

Figure 11. Comparison of apparent activation diameter ( $\left.D_{\text {act }}\right)$ values obtained in this and previous studies, conducted in urban, coastal and forest environments. Mean values for air masses determined to have been influenced by sea-salt transport and biomassburning plumes were calculated for nighttime periods. SS - supersaturation; [1] Quinn et al. (2008); [2] Sihto et al. (2011); [3] Furutani et al. (2008). 
salt events were comparable to those observed for the Atlantic and Pacific Oceans, as well as for the Gulf of Mexico and for aged anthropogenic emissions in California (Furutani et al., 2008; Quinn et al., 2008). Our daytime with vehicular traffic means were comparable to those reported for urban/industrial and freshly polluted air masses in Mexico and California (Quinn et al., 2008), with even the differences being less than statistically significant (Fig. 11).

As can be seen in Fig. 12b, days with vehicular traffic and NPF showed lower AR values than those with vehicular traffic and biomass burning and those with vehicular traffic only, without daytime events. In addition, AR values were slightly different at nighttime. The nighttime increase in AR after NPF events was related to particle growth (Fig. 12b). In relation to $D_{\text {act }}$, during nighttime, biomass-burning events promoted slightly higher $D_{\text {act }}$ values than NPF and sea-salt transport, which is attributable to lower particle hygroscopicity. Although there was a lack of statistical significance, we observed a tendency for biomass burning to affect the air masses arriving at the MASP by decreasing the activation properties.

\section{Summary and conclusions}

The activation of $\mathrm{CCN}$ is quite important to cloud formation and consequently to the hydrological cycle. The aim of this study was to evaluate the variability in $\mathrm{CCN}$ activation parameters under the influence of local sources, remote sources, and NPF, in order to assess the impact of those events on CCN activity in the MASP. The regional atmosphere is highly affected by vehicular traffic emissions, and lower by remote sources such as biomass burning and seasalt transport.

During daytime, PNCs were higher and particle sizes were smaller than during the nighttime periods, a finding that was attributed to fresh vehicular emissions and NPF, whereas the lower PNCs and larger particle sizes observed during the nighttime periods were attributed to the ageing and postgrowth deposition of particles (Fig. 12a). Five NPF events were identified, four being of the class I type. In addition, NPF events were found to have a significant effect on particle size distribution. Biomass-burning and sea-salt air masses were identified by a combination of lidar analysis, HYSPLIT trajectory and PMF analysis and size-distributed chemical composition.

The AR and $D_{\text {act }} \mathrm{CCN}$ activation parameters presented a clear pattern for the daytime (vehicular traffic) and nighttime periods, the daytime period featuring higher $D_{\text {act }}$ and lower AR. The size distribution made a marked contribution to that pattern, according to the assumption that larger particles are more efficient for $\mathrm{CCN}$ activation than smaller particles. That hypothesis is supported by AR and $D_{\text {act }}$ differences between days with and without NPF events. Slight differences for activation parameters could be observed among
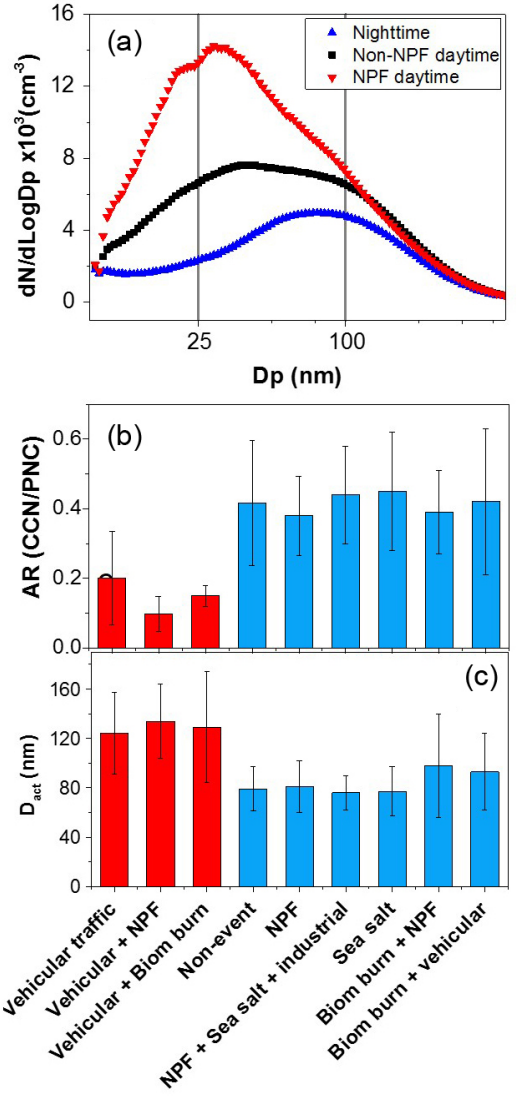

Figure 12. (a) Mean daytime and nighttime particle size. (b) Mean daytime and nighttime activation ratio (AR), during new particle formation (NPF), vehicular traffic, remote source events and nonevent periods. (c) Mean daytime and nighttime apparent activation diameter $\left(D_{\text {act }}\right)$ during NPF, vehicular, remote source events and non-event periods. The AR and $D_{\text {act }}$ were calculated for a supersaturation of $0.4 \%$. Biom burn - biomass burning; PND - particle number distribution.

sea-salt- and biomass-burning-influenced air masses, as well as non-event nighttime periods (Fig. 12c and d). Those slight differences can be explained by complex mixtures between aerosols from local and external sources, the latter traveling longer distances before reaching the measurement site. Dilution, mixing and ageing of aerosols from remote sources occur during travel from the source emission area to the measurement site. The $D_{\text {act }}$ calculated for sea-salt air masses in this study were comparable to that observed over the Atlantic and Pacific Oceans. In summary, our results showed that vehicular traffic during the daytime had greater negative effects on activation parameters than remote sources or vehicular traffic at nighttime. However this evidence must be confirmed by long-term measurements in future studies.

This was the first study to evaluate the effects of vehicular traffic, remote sources and NPF events on CCN activation properties in urban area on South America and only the second to assess CCN variability in the MASP. Our results 
show the influence that vehicular traffic, long-range transport of sea salt, biomass-burning plumes and NPF events have on CCN properties. Therefore, long-term studies covering different seasons and sampling site environments (e.g., coastal, urban and rural) are needed in order to represent $\mathrm{CCN}$ variability more accurately under diverse environmental conditions. An improved understanding of the influence that aerosol composition and provenance have on $\mathrm{CCN}$ activity, real-time monitoring of aerosol chemical composition and $\mathrm{CCN}$ size distribution is also necessary.

\section{Data availability}

All data are available upon request to the authors.

\section{The Supplement related to this article is available online at doi:10.5194/acp-16-14635-2016-supplement.}

Acknowledgements. This work received financial support as part of the University Global Partnership Network (UGPN) for the "Emissions and role of fine aerosol particles in the formation of clouds and precipitation (eRAIN)" project grant, awarded jointly to the Universities of Surrey and São Paulo. This study is also part of a major project entitled "Narrowing the Uncertainties in Aerosol and Climate changes in the state of São Paulo (NUANCE)", funded by the Fundação de Amparo à Pesquisa do Estado de São Paulo (FAPESP, São Paulo Research Foundation). Carlos Eduardo SoutoOliveira is the recipient of a PhD scholarship from the Brazilian Coordenação de Aperfeiçoamento de Pessoal de Nívelk Superior (CAPES, Office for the Advancement of Higher Education).

Edited by: V.-M. Kerminen

Reviewed by: two anonymous referees

\section{References}

Almeida, G. P., Brito, J., Morales, C. A., Andrade, M. F., and Artaxo, P.: Measured and modelled cloud condensation nuclei (CCN) concentration in São Paulo, Brazil: the importance of aerosol size-resolved chemical composition on $\mathrm{CCN}$ concentration prediction, Atmos. Chem. Phys., 14, 7559-7572, doi:10.5194/acp-14-7559-2014, 2014.

An, J., Wang, H., Shen, L., Zhu, B., Zou, J., Gao, J., and Kang, H.: Characteristics of new particle formation events in Nanjing, China: Effect of water-soluble ions, Atmos. Environ., 108, 3240, doi:10.1016/j.atmosenv.2015.01.038, 2015.

Andrade, M. F., Orsini, C., and Maenhaut, W.: Relation between aerosol sources and meteorological parameters for inhalable atmospheric particles in Sao Paulo City, Brazil, Atmos. Environ., 28, 2307-2315, doi:10.1016/1352-2310(94)90484-7, 1994.
Andrade, M. F., De Miranda, R. M., Fornaro, A., Kerr, A., Oyama, B., De Andre, P. A., and Saldiva, P.: Vehicle emissions and $\mathrm{PM}_{2.5}$ mass concentrations in six Brazilian cities, Air Qual. Atmos. Health, 5, 79-88, doi:10.1007/s11869-010-0104-5, 2012.

Andreae, M. O.: The aerosol nucleation puzzle, Science, 339, 911912, doi:10.1126/science.1233798, 2013.

Andreae, M. O. and Rosenfeld, D.: Aerosol-cloudprecipitation interactions. Part 1 . The nature and sources of cloud-active aerosols, Earth-Sci. Rev., 89, 13-41, doi:10.1016/j.earscirev.2008.03.001, 2008.

Andreae, M. O., Rosenfeld, D., Artaxo, P., Costa, A. A., Frank, G. P., Longo, K. M., and Silva-Dias, M. A. F.: Smoking rain clouds over the Amazon, Science, 303, 1337-1342, doi:10.1126/science.1092779, 2004.

Baars, H., Kanitz, T., Engelmann, R., Althausen, D., Heese, B., Komppula, M., Preißler, J., Tesche, M., Ansmann, A., Wandinger, U., Lim, J.-H., Ahn, J. Y., Stachlewska, I. S., Amiridis, V., Marinou, E., Seifert, P., Hofer, J., Skupin, A., Schneider, F., Bohlmann, S., Foth, A., Bley, S., Pfüller, A., Giannakaki, E., Lihavainen, H., Viisanen, Y., Hooda, R. K., Pereira, S. N., Bortoli, D., Wagner, F., Mattis, I., Janicka, L., Markowicz, K. M., Achtert, P., Artaxo, P., Pauliquevis, T., Souza, R. A. F., Sharma, V. P., van Zyl, P. G., Beukes, J. P., Sun, J., Rohwer, E. G., Deng, R., Mamouri, R.-E., and Zamorano, F.: An overview of the first decade of Polly NET: an emerging network of automated Raman-polarization lidars for continuous aerosol profiling, Atmos. Chem. Phys., 16, 5111-5137, doi:10.5194/acp-165111-2016, 2016.

Backman, J., Rizzo, L. V., Hakala, J., Nieminen, T., Manninen, H. E., Morais, F., Aalto, P. P., Siivola, E., Carbone, S., Hillamo, R., Artaxo, P., Virkkula, A., Petäjä, T., and Kulmala, M.: On the diurnal cycle of urban aerosols, black carbon and the occurrence of new particle formation events in springtime São Paulo, Brazil, Atmos. Chem. Phys., 12, 11733-11751, doi:10.5194/acp12-11733-2012, 2012.

Betha, R., Spracklen, D. V., and Balasubramanian, R.: Observations of new aerosol particle formation in a tropical urban atmosphere, Atmos. Environ., 71, 340-351, doi:10.1016/j.atmosenv.2013.01.049, 2013.

Bouéres, L. C. S. and Orsini, C. M. Q.: Fine and coarse elemental components in the urban aerosol of São Paulo, Brazil, Nucl. Instrum. Methods, 181, 417-424, doi:10.1016/0029554x(81)90643-1, 1981.

Bougiatioti, A., Nenes, A., Fountoukis, C., Kalivitis, N., Pandis, S. N., and Mihalopoulos, N.: Size-resolved CCN distributions and activation kinetics of aged continental and marine aerosol, Atmos. Chem. Phys., 11, 8791-8808, doi:10.5194/acp-11-87912011, 2011.

Burkart, J., Steiner, G., Reischl, G., and Hitzenberger. R.: Longterm study of cloud condensation nuclei $(\mathrm{CCN})$ activation of the atmospheric aerosol in Vienna, Atmos. Environ., 45, 5751-5759, doi:10.1016/j.atmosenv.2011.07.022, 2011.

Bzdek, B. R., Pennington, M. R., and Johnston, M. V.: Single particle chemical analysis of ambient ultrafine aerosol: A review, J. Aerosol Sci., 52, 109-120, doi:10.1016/j.jaerosci.2012.05.001, 2012.

Calvo, A. I., Alves, C., Castro, A., Pont, V., Vicente, A. M., and Fraile, R.: Research on aerosol sources and chemical composi- 
tion: Past, current and emerging issues, Atmos. Res., 120-121, 1-28, doi:10.1016/j.atmosres.2012.09.021, 2013.

Castanho, D. A. and Artaxo, P.: Wintertime and summertime São Paulo aerosol source apportionment study, Atmos. Environ., 35, 4889-4902, doi:10.1016/s1352-2310(01)00357-0, 2001.

Cheung, H. C., Morawska, L., and Ristovski, Z. D.: Observation of new particle formation in subtropical urban environment, Atmos. Chem. Phys., 11, 3823-3833, doi:10.5194/acp-11-38232011, 2011.

Dal Maso, M., Kulmala, M., Riipinen, I., Wagner, R., Hussein, T., Aalto, P. P., and Lehtinen, K. E. J. Formation and growth of fresh atmospheric aerosols: eight years of aerosol size distribution data from SMEAR II, Hyytiala, Finland, Boreal Environ. Res., 10, 323-336, 2005.

Deng, Z. Z., Zhao, C. S., Ma, N., Ran, L., Zhou, G. Q., Lu, D. R., and Zhou, X. J.: An examination of parameterizations for the $\mathrm{CCN}$ number concentration based on in situ measurements of aerosol activation properties in the North China Plain, Atmos. Chem. Phys., 13, 6227-6237, doi:10.5194/acp-13-62272013, 2013.

Donahue, N. M., Ortega, I. K., Chuang, W., Riipinen, I., Riccobono, F., Schobesberger, S., Dommen, J., Baltensperger, U., Kulmala, M., Worsnopbe, D. R., and Vehkamaki, H.: How do organic vapors contribute to new-particle formation?, Faraday Discuss., 165, 91-104, doi:10.1039/c3fd00046j, 2013.

Draxler, R. and Hess G.: Description of the hysplit 4 modeling system, NOAA Tech. Memo. ERL ARL-224, NOAA Air Resources Laboratory, available at: http://ready.arl.noaa.gov/ HYSPLIT.php, last access: 2 December 2003.

Draxler, R. and Rolph, G: HYSPLIT (Hybrid Single-Particle Lagrangian Integrated Trajectory) Model, NOAA Air Resources Laboratory, available at: http://www.arl.noaa.gov/ready/hysplit4. html, last access: 20 November 2015.

Dusek, U., Frank, G. P., Curtius, J., Drewnick, F., Schneider, J., Kürten, A., and Pöschl, U.: Enhanced organic mass fraction and decreased hygroscopicity of cloud condensation nuclei (CCN) during new particle formation events, Geophys. Res. Lett., 37, L03804, doi:10.1029/2009g1040930, 2010

CETESB, Environmental Protection Agency of São Paulo Estate: Air quality report for the State of São Paulo 2015, available at: http://ar.cetesb.sp.gov.br/publicacoes-relatorios/ (last access: 10 June 2016), 2015 (in Portuguese).

Fernald, F. G.: Analysis of atmospheric lidar observations: some comments, Appl. Optics, 23, 652-653, doi:10.1364/AO.23.000652, 1984.

Frank, G. P., Dusek, U., and Andreae, M. O.: Technical note: A method for measuring size-resolved $\mathrm{CCN}$ in the atmosphere, Atmos. Chem. Phys. Discuss., 6, 4879-4895, doi:10.5194/acpd-64879-2006, 2006.

Freitas, E. D., Rozoff, C. M., and Cotton, W. R.: Interactions of an urban heat island and sea-breeze circulations during winter over the metropolitan area of São Paulo, Brazil, Bound.-Lay. Meteorol., 122, 43-65, doi:10.1007/s10546-006-9091-3, 2007.

Freud, E., Rosenfeld, D., Andreae, M. O., Costa, A. A., and Artaxo, P.: Robust relations between $\mathrm{CCN}$ and the vertical evolution of cloud drop size distribution in deep convective clouds, Atmos. Chem. Phys., 8, 1661-1675, doi:10.5194/acp-8-1661-2008, 2008
Furutani, H., Dall, M., Roberts, G. C., and Prather, K. A.: Assessment of the relative importance of atmospheric aging on $\mathrm{CCN}$ activity derived from field observations, Atmos. Environ., 42, 3130-3142, doi:10.1016/j.atmosenv.2007.09.024, 2008.

Gioia, S. M. C. L., Babinski, M., Weiss, D. J., and Kerr, A. A. F. S.: Insights into the dynamics and sources of atmospheric lead and particulate matter in São Paulo, Brazil, from high temporal resolution sampling, Atmos. Res., 98, 478-485, doi:10.1016/j.atmosres.2010.08.016, 2010.

Gómez-Moreno, F. J., Pujadas, M., Plaza, J., Rodríguez-Maroto, J. J., Martínez-Lozano, P., and Artíñano, B.: Influence of seasonal factors on the atmospheric particle number concentration and size distribution in Madrid, Atmos. Environ., 45, 3169-3180, doi:10.1016/j.atmosenv.2011.02.041, 2011.

Guerrero-Rascado, J. L., Landulfo, E., Antuña, J. C., Barbosa, H. M. J., Barja, B, Bastidas, A. E., Bedoya, A. E., da Costa, R. F., Estevan, R., Forno, R. N., Gouveia, D. A., Jimenez, C., Larroza, E. G., Lopes, F. J. S., Montilla-Rosero, E., Moreira, G. A., Nakaema, W. M., Nisperuza, D., Alegria, D., Múnera, M., Otero, L., Papandrea, S., Pawelko, E., Quel, E. J., Ristori, P., Rodrigues, P. F., Salvador, J., Sánchez, M. F., and Silva, A.: Towards an instrumental harmonization in the framework of LALINET: dataset of technical specifications, Proc. SPIE 9246, Lidar Technologies, Techniques, and Measurements for Atmospheric Remote Sensing X, 92460O, doi:10.1117/12.2066873, 2014.

Guerrero-Rascado, J. L., Landulfo, E., Antuña, J. C., Barbosa, H. M. J., Barja, B, Bastidas, A. E., Bedoya, A. E., da Costa, R. F., Estevan, R., Forno, R. N., Gouveia, D. A., Jimenez, C., Larroza, E. G., Lopes, F. J. S., Montilla-Rosero, E., Moreira, G. A., Nakaema, W. M., Nisperuza, D., Alegria, D., Múnera, M., Otero, L., Papandrea, S., Pawelko, E., Quel, E. J., Ristori, P., Rodrigues, P. F., Salvador, J., Sánchez, M. F., and Silva, A.: Latin American Lidar Network (LALINET) for aerossol research: Diagnosis on network instrumentation, J. Atmos. Sol.-Terr. Phy., 138-139, 112-120, doi:10.1016/j.jastp.2016.01.001, 2016.

Gunthe, S. S., Rose, D., Su, H., Garland, R. M., Achtert, P., Nowak, A., Wiedensohler, A., Kuwata, M., Takegawa, N., Kondo, Y., Hu, M., Shao, M., Zhu, T., Andreae, M. O., and Pöschl, U.: Cloud condensation nuclei $(\mathrm{CCN})$ from fresh and aged air pollution in the megacity region of Beijing, Atmos. Chem. Phys., 11, 1102311039, doi:10.5194/acp-11-11023-2011, 2011.

Hallquist, M., Wenger, J. C., Baltensperger, U., Rudich, Y., Simpson, D., Claeys, M., Dommen, J., Donahue, N. M., George, C., Goldstein, A. H., Hamilton, J. F., Herrmann, H., Hoffmann, T., Iinuma, Y., Jang, M., Jenkin, M. E., Jimenez, J. L., Kiendler-Scharr, A., Maenhaut, W., McFiggans, G., Mentel, Th. F., Monod, A., Prévôt, A. S. H., Seinfeld, J. H., Surratt, J. D., Szmigielski, R., and Wildt, J.: The formation, properties and impact of secondary organic aerosol: current and emerging issues, Atmos. Chem. Phys., 9, 5155-5236, doi:10.5194/acp-9-51552009, 2009.

Heal, M. R., Kumar, P., and Harrison, R. M.: Particles, Air Quality, Policy and Health, Chem. Soc. Rev., 41, 6606-6630, doi:10.1039/c2cs35076a, 2012.

Hetem, I. G. and Andrade, M. F.: Characterization of fine particulate matter emitted from the resuspension of road and pavement dust in the Metropolitan Area of São Paulo, Brazil, Atmosphere, 7, 31-41, doi:10.3390/atmos7030031, 2016. 
Holben, B. N., Eck, T. F., Slutsker, I., Tanré, D., Buis, J. P., Setzer, A., Vermote, E., Reagan, J. A., Kaufman, Y. J., Nakajima, T., Lavenu, T. Jankowiak, I., and Smirnov, A.: Aeronet - A Federal Instrument Network and Data Archive for Aerosol Characterization, Remote Sens. Environ., 66, 1-16, doi:10.1016/S00344257(98)00031-5, 1998.

Holmes, N. S.: A review of particle formation events and growth in the atmosphere in the various environments and discussion of mechanistic implications, Atmos. Environ., 41, 2183-2201, doi:10.1016/j.atmosenv.2006.10.058, 2007.

IBGE, Brazilian Institute of Geography and Statistics: Atlas of the 2010 Population Census, available at: http://www.ibge.gov.br/ english/ (last access: 1 January 2016), 2010.

IPCC: Climate change 2013, Scientific basis, Fifth assessment of the Intergovernmental Panel on Climate Change, available at: http://www.ipcc.ch/report/ar5/wg1/ (last access: 10 February 2015), 2013.

Kalafut-Pettibone, A. J., Wang, J., Eichinger, W. E., Clarke, A., Vay, S. A., Blake, D. R., and Stanier, C. O.: Size-resolved aerosol emission factors and new particle formation/growth activity occurring in Mexico City during the MILAGRO 2006 Campaign, Atmos. Chem. Phys., 11, 8861-8881, doi:10.5194/acp-11-88612011, 2011.

Karavalakis, G., Boutsika, V., Stournas, S., and Bakeas, E.: Biodiesel emissions profile in modern diesel vehicles. Part 2: Effect of biodiesel origin on carbonyl, $\mathrm{PAH}$, nitro-PAH and oxy-PAH emissions, Sci. Total Environ., 409, 938-747, doi:10.1016/j.scitotenv.2010.11.010, 2011.

Klett, J. D.: Stable analytical inversion solution for processing lidar returns, Appl. Optics, 20, 211-220, doi:10.1364/ao.20.000211, 1981.

Klett, J. D.: Lidar calibration and extinction coefficients, Appl. Optics, 22, 514-515, doi:10.1364/ao.22.000514, 1983.

Kroll, J. H. and Seinfeld, J. H.: Chemistry of secondary organic aerosol: Formation and evolution of low-volatility organics in the atmosphere, Atmos. Environ., 42, 3593-3624, doi:10.1016/j.atmosenv.2008.01.003, 2008.

Kulmala, M., Vehkamaki, H., Petäjä, T., Dal Maso, M., Lauri, A., Kerminen, V. M., Birmili, W., and McMurry, P. H.: Formation and growth rates of ultrafine atmospheric particles: a review of observations, J. Aerosol Sci., 35, 143-176, doi:10.1016/j.jaerosci.2003.10.003, 2004.

Kumar, P., Robins, A., Vardoulakis, S., and Britter, R.: A review of the characteristics of nanoparticles in the urban atmosphere and the prospects for developing regulatory control, Atmos. Environ., 44, 5035-5052, doi:10.1016/j.atmosenv.2010.08.016, 2010.

Kumar, P., Morawska, L., Birmili, W., Paasonen, P., Hu, M., Kulmala, M., Harrison, R. M., Norford, L., and Britter, R.: Ultrafine particles in cities, Environ. Int., 66, 1-10, doi:10.1016/j.envint.2014.01.013, 2014.

Kumar, P., Andrade, M. F., Ynoue, R. Y., Fornaro, A., de Freitas, E. D., Martins, J., Martins, L. D., Albuquerque, T., Zhang, Y., and Morawska, L.: New Directions: From biofuels to wood stoves: the modern and ancient air quality challenges in the megacity of São Paulo, Atmos. Environ., 140, 364-369, doi:10.1016/j.atmosenv.2016.05.059, 2016.

Leng, C., Cheng, T., Chen, J., Zhang, R., Tao, J., Huang, G., and Li, L.: Measurements of surface cloud condensation nuclei and aerosol activity in downtown Shanghai, Atmos. Environ., 69, 354-361, doi:10.1016/j.atmosenv.2012.12.021, 2013.

Long, B., Tan, X. F., Wang, Y. B., Li, J., Ren, D. S., and Zhang, W. J.: Theoretical Studies on Reactions of $\mathrm{OH}$ with $\mathrm{H}_{2} \mathrm{SO}_{4} \cdots \mathrm{NH}_{3}$ Complex and $\mathrm{NH}_{2}$ with $\mathrm{H}_{2} \mathrm{SO}_{4}$ in the Presence of Water, Chemistry Select, 1, 1421-1430, doi:10.1002/slct.201600194, 2016.

Ma, N. and Birmili, W.: Estimating the contribution of photochemical particle formation to ultrafine particle number averages in an urban atmosphere, Sci. Total Environ., 512, 154-166, doi:10.1016/j.scitotenv.2015.01.009, 2015.

Marenco, F., Santacesaria, V., Bais, A. F., Balis, D., di Sarra, A., Papayannis, A., and Zerefos, C.: Optical properties of tropospheric aerosols determined by lidar and spectrophotometric measurements (Photochemical Activity and Solar Ultraviolet Radiation campaign), Appl. Optics, 36, 6875-6886, doi:10.1364/AO.36.006875, 2002.

McFiggans, G., Artaxo, P., Baltensperger, U., Coe, H., Facchini, M. C., Feingold, G., Fuzzi, S., Gysel, M., Laaksonen, A., Lohmann, U., Mentel, T. F., Murphy, D. M., O’Dowd, C. D., Snider, J. R., and Weingartner, E.: The effect of physical and chemical aerosol properties on warm cloud droplet activation, Atmos. Chem. Phys., 6, 2593-2649, doi:10.5194/acp-6-2593-2006, 2006.

Metzger, A., Verheggen, B., Dommen, J., Duplissy, J., Prevot, A. S. H., Weingartner, E., Riipinenc, I., Kulmalac, M., Spracklend, D. V., Carslawd, K. S., and Baltensperger, U.: Evidence for the role of organics in aerosol particle formation under atmospheric conditions, P. Natl. Acad. Sci. USA, 107, 6646-6651, doi:10.1073/pnas.0911330107, 2010.

Monks, P. S., Archibald, A. T., Colette, A., Cooper, O., Coyle, M., Derwent, R., Fowler, D., Granier, C., Law, K. S., Mills, G. E., Stevenson, D. S., Tarasova, O., Thouret, V., von Schneidemesser, E., Sommariva, R., Wild, O., and Williams, M. L.: Tropospheric ozone and its precursors from the urban to the global scale from air quality to short-lived climate forcer, Atmos. Chem. Phys., 15, 8889-8973, doi:10.5194/acp-15-8889-2015, 2015.

Müller, D., Ansmann, A., Mattis, I., Tesche, M., Wandinger, U., Althausen, D., and Pisani, G.: Aerosol-type-dependent lidar ratios observed with raman lidar, J. Geophys. Res., 112, D16202, doi:10.1029/2006jd008292, 2007.

Nie, W., Ding, A., Wang, T., Kerminen, V.-M., George, C., Xue, L., and Kulmala, M.: Polluted dust promotes new particle formation and growth, Nature, 4, 6634, doi:10.1038/srep06634, 2014.

Oliveira, A. P., Bornstein, R. D., and Soares, J.: Annual and diurnal wind patterns in the city of São Paulo, Water Air Soil Poll., 3, 3-15, doi:10.1023/A:1026090103764, 2003.

Ortega, A. M., Hayes, P. L., Peng, Z., Palm, B. B., Hu, W., Day, D. A., Li, R., Cubison, M. J., Brune, W. H., Graus, M., Warneke, C., Gilman, J. B., Kuster, W. C., de Gouw, J., Gutiérrez-Montes, C., and Jimenez, J. L.: Real-time measurements of secondary organic aerosol formation and aging from ambient air in an oxidation flow reactor in the Los Angeles area, Atmos. Chem. Phys., 16, 7411-7433, doi:10.5194/acp-16-7411-2016, 2016.

Oyama, B. S., Andrade, M. F., Herckes, P., Dusek, U., Röckmann, T., and Holzinger, R.: Vehicular emissions of organic particulate matter in Sao Paulo, Brazil, Atmos. Chem. Phys. Discuss., 15, 33755-33788, doi:10.5194/acpd-15-33755-2015, 2015.

Paramonov, M., Aalto, P. P., Asmi, A., Prisle, N., Kerminen, V.M., Kulmala, M., and Petäjä, T.: The analysis of size-segregated cloud condensation nuclei counter (CCNC) data and its impli- 
cations for cloud droplet activation, Atmos. Chem. Phys., 13, 10285-10301, doi:10.5194/acp-13-10285-2013, 2013.

Peng, J. F., Hu, M., Wang, Z. B., Huang, X. F., Kumar, P., Wu, Z. J., Guo, S., Yue, D. L., Shang, D. J., Zheng, Z., and He, L. Y.: Submicron aerosols at thirteen diversified sites in China: size distribution, new particle formation and corresponding contribution to cloud condensation nuclei production, Atmos. Chem. Phys., 14, 10249-10265, doi:10.5194/acp-14-10249-2014, 2014.

Pierce, J. R., Leaitch, W. R., Liggio, J., Westervelt, D. M., Wainwright, C. D., Abbatt, J. P. D., Ahlm, L., Al-Basheer, W., Cziczo, D. J., Hayden, K. L., Lee, A. K. Y., Li, S.-M., Russell, L. M., Sjostedt, S. J., Strawbridge, K. B., Travis, M., Vlasenko, A., Wentzell, J. J. B., Wiebe, H. A., Wong, J. P. S., and Macdonald, A. M.: Nucleation and condensational growth to CCN sizes during a sustained pristine biogenic SOA event in a forested mountain valley, Atmos. Chem. Phys., 12, 3147-3163, doi:10.5194/acp-12-3147-2012, 2012.

Quinn, P. K., Bates, T. S., Coffman, D. J., and Covert, D. S.: Influence of particle size and chemistry on the cloud nucleating properties of aerosols, Atmos. Chem. Phys., 8, 1029-1042, doi:10.5194/acp-8-1029-2008, 2008.

Reade, L., Jennings, S. G., and McSweeney, G.: Cloud condensation nuclei measurements at Mace Head, Ireland, over the period 1994-2002, Atmos. Res., 82, 610-621, doi:10.1016/j.atmosres.2006.02.017, 2006.

Reche, C., Querol, X., Alastuey, A., Viana, M., Pey, J., Moreno, T., Rodríguez, S., González, Y., Fernández-Camacho, R., de la Rosa, J., Dall'Osto, M., Prévôt, A. S. H., Hueglin, C., Harrison, R. M., and Quincey, P.: New considerations for PM, Black Carbon and particle number concentration for air quality monitoring across different European cities, Atmos. Chem. Phys., 11, 6207-6227, doi:10.5194/acp-11-6207-2011, 2011.

Reff, A., Eberly, S. I., and Bhave, P. V.: Receptor Modeling of Ambient Particulate Matter Data Using Positive Matrix Factorization: Review of Existing Methods Receptor Modeling of Ambient Particulate Matter Data Using Positive Matrix Factorization, J. Air Waste Manage., 57, 146-154, doi:10.1080/10473289.2007.10465319, 2007.

Remer, L. A., Kaufman, Y. J., Tanré, D., Mattoo, S., Chu, D. A., Martins, J. V., Li, R. R., Ichoku, C., Levy, R. C., Kleidman, R. G., Eck, T. F., Vermote, E., and Holben, B. N.: The MODIS aerosol algorithm, products, and validation, J. Atmos. Sci., 62, 947-973, doi:10.1175/JAS3385.1, 2005.

Riipinen, I., Pierce, J. R., Yli-Juuti, T., Nieminen, T., Häkkinen, S., Ehn, M., Junninen, H., Lehtipalo, K., Petäjä, T., Slowik, J., Chang, R., Shantz, N. C., Abbatt, J., Leaitch, W. R., Kerminen, V.-M., Worsnop, D. R., Pandis, S. N., Donahue, N. M., and Kulmala, M.: Organic condensation: a vital link connecting aerosol formation to cloud condensation nuclei (CCN) concentrations, Atmos. Chem. Phys., 11, 3865-3878, doi:10.5194/acp-11-38652011, 2011.

Roberts, G. C. and Nenes, A.: A Continuous-Flow Streamwise Thermal-Gradient $\mathrm{CCN}$ Chamber for Atmospheric Measurements, Aerosol Sci. Technol., 39, 206-221, doi:10.1080/027868290913988, 2005.

Rodrigues, P. F., Landulfo, E., Gandu, A. W., and Lopes, F. J. S.: Assessment of aerosol hygroscopic growth using an elastic LIDAR and BRAMS simulation in urban metropolitan areas, AIP Conf. Proc., 1531, 360-363, doi:10.1063/1.4804781, 2013.
Sanchez-Ccoyllo, O. R. and Andrade, M. F.: The influence of meteorological conditions on the behavior of pollutants concentrations in São Paulo, Brazil, Environ. Pollut., 116, 257-263, doi:10.1016/S0269-7491(01)00129-4, 2002.

Sánchez-Ccoyllo, O. R., Ynoue, R. Y., Martins, L. D., Astolfo, R., Miranda, R. M., Freitas, E. D., Borges, A. S., Fornaro, A., Freitas, H., Moreira, A., and Andrade, M. F.: Vehicular particulate matter emissions in road tunnels in São Paulo, Brazil, Environ. Monit. Assess., 149, 241-249, doi:10.1007/s10661-008-0198-5, 2008.

Sasano, Y. and Nakane, H.: Significance of the extinction/backscatter ratio and the boundary value term in the solution for the two-component lidar equation, Appl. Optics, 23, 1-13, doi:10.1364/AO.23.0011_1, 1984.

Shilling, J. E., Zaveri, R. A., Fast, J. D., Kleinman, L., Alexander, M. L., Canagaratna, M. R., Fortner, E., Hubbe, J. M., Jayne, J. T., Sedlacek, A., Setyan, A., Springston, S., Worsnop, D. R., and Zhang, Q.: Enhanced SOA formation from mixed anthropogenic and biogenic emissions during the CARES campaign, Atmos. Chem. Phys., 13, 2091-2113, doi:10.5194/acp-13-20912013, 2013.

Sihto, S.-L., Mikkilä, J., Vanhanen, J., Ehn, M., Liao, L., Lehtipalo, K., Aalto, P. P., Duplissy, J., Petäjä, T., Kerminen, V.-M., Boy, M., and Kulmala, M.: Seasonal variation of CCN concentrations and aerosol activation properties in boreal forest, Atmos. Chem. Phys., 11, 13269-13285, doi:10.5194/acp-11-13269-2011, 2011.

Silva, M. F., Assunção, J. V., Andrade, M. F., and Pesquero, C.: Characterization of metal and trace element contents of particulate matter $\left(\mathrm{PM}_{10}\right)$ emitted by vehicles running on Brazilian fuels - hydrated ethanol and gasoline with $22 \%$ of anhydrous ethanol, J. Toxicol. Env. Health, A73, 901-909, doi:10.1080/15287391003744849, 2010.

Sorribas, M., Adame, J. A., Olmo, F. J., Vilaplana, J. M., Gil-Ojeda, M., and Alados-Arboledas, L.: A long-term study of new particle formation in a coastal environment: meteorology, gas phase and solar radiation implications, Sci. Total Environ., 511, 72337, doi:10.1016/j.scitotenv.2014.12.011, 2015.

Taiwo, A. M., Harrison, R. M., and Shi, Z.: A review of receptor modelling of industrially emitted particulate matter, Atmos. Environ., 97, 109-120, doi:10.1016/j.atmosenv.2014.07.051, 2014.

Vara-Vela, A., Andrade, M. F., Kumar, P., Ynoue, R. Y., and Muñoz, A. G.: Impact of vehicular emissions on the formation of fine particles in the Sao Paulo Metropolitan Area: a numerical study with the WRF-Chem model, Atmos. Chem. Phys., 16, 777-797, doi:10.5194/acp-16-777-2016, 2016.

Wallington, T. J., Anderson, J., Kurtz, E. M., and Tennison P. J.: Biofuels, vehicle emissions, and urban air quality, Faraday Discuss., 189, 121-136, doi:10.1039/c5fd00205b, 2016.

Yuan, B., Hu, W. W., Shao, M., Wang, M., Chen, W. T., Lu, S. H., Zeng, L. M., and Hu, M.: VOC emissions, evolutions and contributions to SOA formation at a receptor site in eastern China, Atmos. Chem. Phys., 13, 8815-8832, doi:10.5194/acp-13-88152013, 2013.

Yue, D. L., Hu, M., Zhang, R. Y., Wu, Z. J., Su, H., Wang, Z. B., and Wiedensohler, A.: Potential contribution of new particle formation to cloud condensation nuclei in Beijing, Atmos. Environ., 45, 6070-6077, doi:10.1016/j.atmosenv.2011.07.037, 2011.

Yum, S. S., James, G. H., Keun, Y. S., and Byoung-Cheol, C.: Springtime cloud condensation nuclei concentrations on 
the west coast of Korea, Geophys. Res. Lett., 32, L09814, doi:10.1029/2005g1022641, 2005.

Zhang, F., Li, Y., Li, Z., Sun, L., Li, R., Zhao, C., Wang, P., Sun, Y., Liu, X., Li, J., Li, P., Ren, G., and Fan, T.: Aerosol hygroscopicity and cloud condensation nuclei activity during the $\mathrm{AC}^{3} \mathrm{Exp}$ campaign: implications for cloud condensation nuclei parameterization, Atmos. Chem. Phys., 14, 13423-13437, doi:10.5194/acp14-13423-2014, 2014.
Zhu, Y., Sabaliauskas, K., Liu, X., Meng, H., Gao, H., Jeong, C. H., Evans, G. J., and Yao, X.: Comparative analysis of new particle formation events in less and severely polluted urban atmosphere, Atmos. Environ., 98, 655-664, doi:10.1016/j.atmosenv.2014.09.043, 2014. 